Article

\title{
Delta Project: Towards a Sustainable Campus
}

\author{
Héctor Hugo ${ }^{1, * \mathbb{C}}$, Felipe Espinoza ${ }^{1}$, Ivetheyamel Morales ${ }^{1}$, Elías Ortiz $^{2}$, Saúl Pérez ${ }^{3}$ and \\ Galo Salcedo ${ }^{4}$ \\ 1 School of Architecture and Urbanism, University of Guayaquil, Cdla. Universitaria "Salvador Allende", \\ Guayaquil 090510, Ecuador; felipe.espinozao@ug.edu.ec (F.E.); ivetheyamel.moralesv@ug.edu.ec (I.M.) \\ 2 School of Administrative Sciences, University of Guayaquil, Cdla. Universitaria "Salvador Allende", \\ Guayaquil 090510, Ecuador; elias.ortizmor@ug.edu.ec \\ 3 Department of University Works, University of Guayaquil, Cdla. Universitaria "Salvador Allende", \\ Guayaquil 090510, Ecuador; saullgcurve@gmail.com \\ 4 School of Sciences for Development, University of Guayaquil, Cdla. Universitaria "Salvador Allende", \\ Guayaquil 090510, Ecuador; galo.salcedor@ug.edu.ec \\ * Correspondence: hector.hugou@ug.edu.ec; Tel.: +593-988912004
}

Received: 23 June 2018; Accepted: 16 September 2018; Published: 15 October 2018

check for updates

\begin{abstract}
The University of Guayaquil, which shares the same name as the city where it is located, faces the challenge of its image transformation for the 21st century. It was deemed necessary to identify details about the urban evolution of the city over time, in relation to the changes produced by the project's site and its direct area of influence. The goal is to integrate the main university campus within a framework which guarantees sustainability and allows innovation in the living lab. To achieve this, the action research method was applied, focused on the community participation and the logic framework. The proposal, the management model, and the integrated working groups were organized with internal users such as professors, students, and university authorities, and external actors such as residents, local business communities, Guayaquil city council, and its local mayor and governor. As result of the diagnosis, six different analysis dimensions were established which correspond to the new urban agenda for the future campus: compactness, inclusiveness, resilience, sustainability, safety, and participation. As a proposal, the urban design integrates the analysis of the dimensions whose financial support and execution are given by the municipality authorities that integrates the campus with its network of community police headquarters.
\end{abstract}

Keywords: sustainability; university living lab; management model

\section{Introduction}

Urbanization and its areas belong to a set of worldwide, multiscale phenomena that are profoundly altering the relationship between society and the environment, affecting green areas, sustainability, and resilience in complex ways at alarming rates. In recent decades, sustainability, resilience, and transformation have become key concepts aimed to answer an array of looming challenges posed by urbanization and environmental change [1].

Guayaquil University (See Figure 1), is located in the city of Guayaquil in the Republic of Ecuador, is the country's biggest and oldest University. It is located in the north of the city in the Tarqui parish inside Salvador Allende citadel, Malecon del Salado waterfront, and Delta and Kennedy Avenue. 


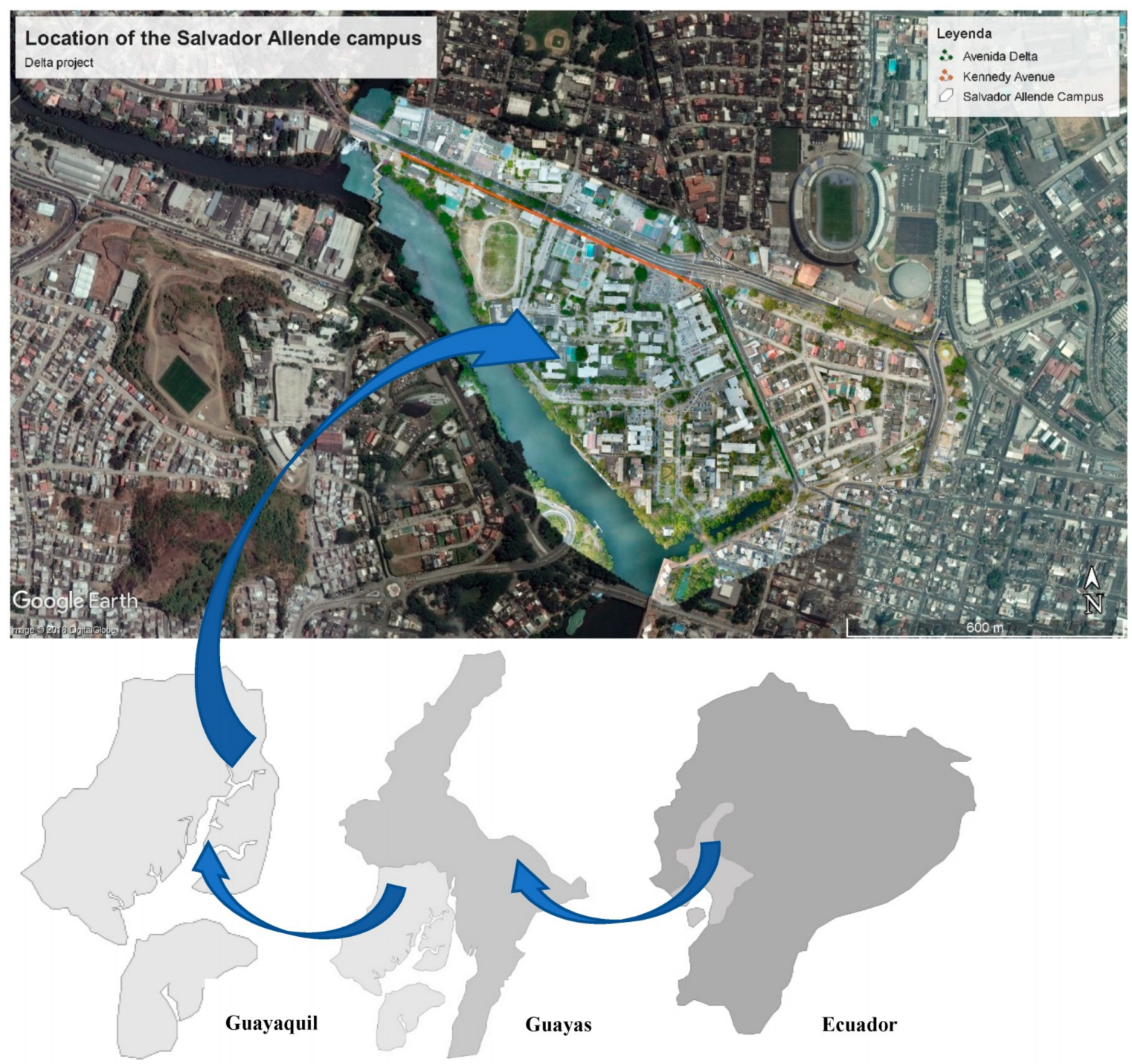

Figure 1. Location of the Salvador Allende campus.

This university had passed through a foundational process that began in 1843 , driven by the aspiration of the residents to receive professional training in their hometown. After several attempts to establish the university, the educative entity was finally defined in 1897. It was the first university in Ecuador to welcome a new reform, initiated in 1918 at the National University of Córdoba (Argentina), that first promoted undergraduate students, cogovernment, and the freedom of professorship. At the end of the 19th century, it occupied an empty lot placed on Pedro Carbo Street (See Figure 2a), but it moved to its current principal campus between 1949 and 1954 (See Figure 2b).

During its history, many characters of great transcendence in the political field and other areas have been part of the university student body, as well as its teachers and governing body. Throughout its existence, and as result of a misunderstood autonomy and the background of political instability in the country, urban limitations were established; enclosures were built, causing a serious fragmentation to the public university space and a detriment of the university community. An urban integration proposal between Salvador Allende citadel and the rest of the city through the Delta Project, which consists of a pedestrian circuit incorporating the public and natural spaces, recalls the pattern of integration of the natural ecologic corridor which existed in Guayaquil in the 18th century, but which gradually disappeared during the 19th century (See Figure 3a,b). 


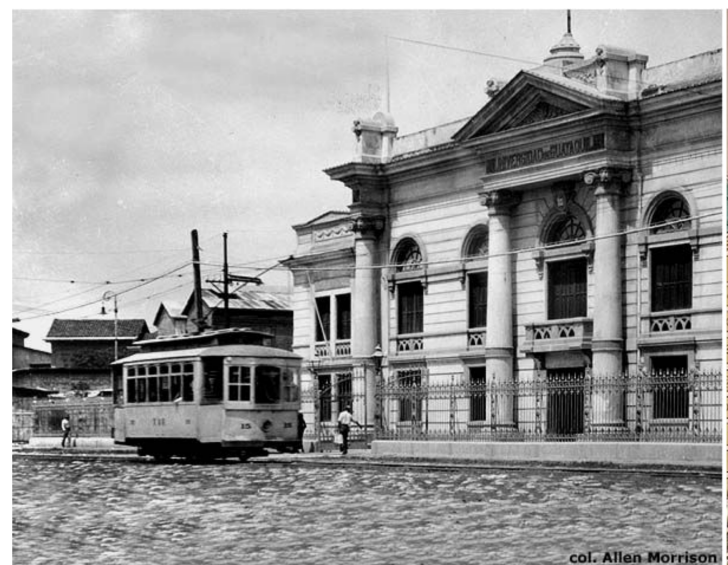

(a)

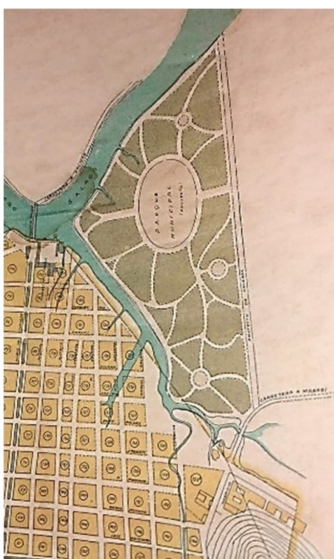

(b)

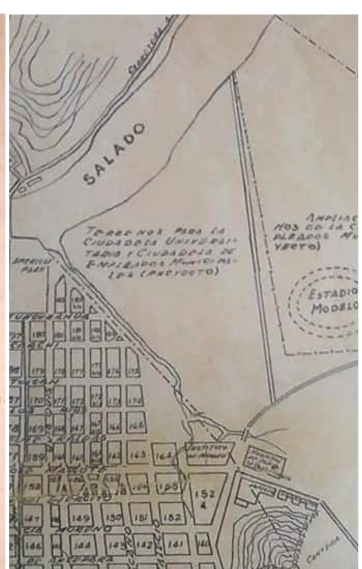

Figure 2. Chronological data collection of Guayaquil [2]. (a) First university house of Guayaquil University. Built during the period of Doctor Julian Coronel's directorship. The workmanship was charged to the architect Rocco Queirolo and was concluded in 1906. The property was declared to be under Cultural National Patrimony on 26 February 1988; (b) The land was originally projected as a Municipal Park in 1944. On the right, in 1946, it can be seen how the land use was changed for the university citadel and municipality employees.

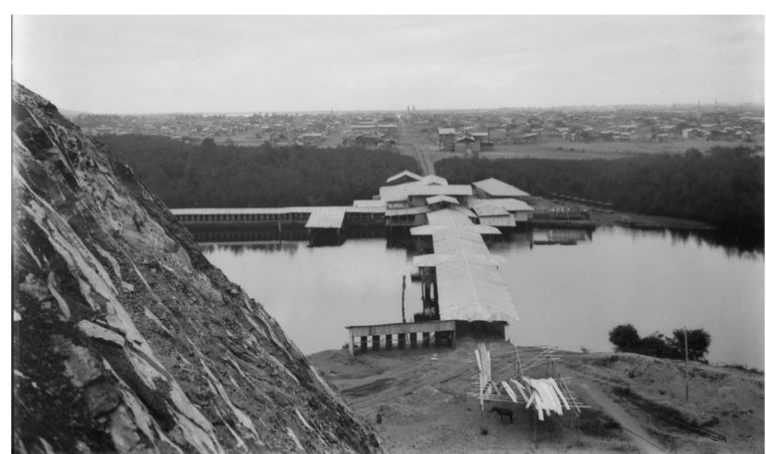

(a)

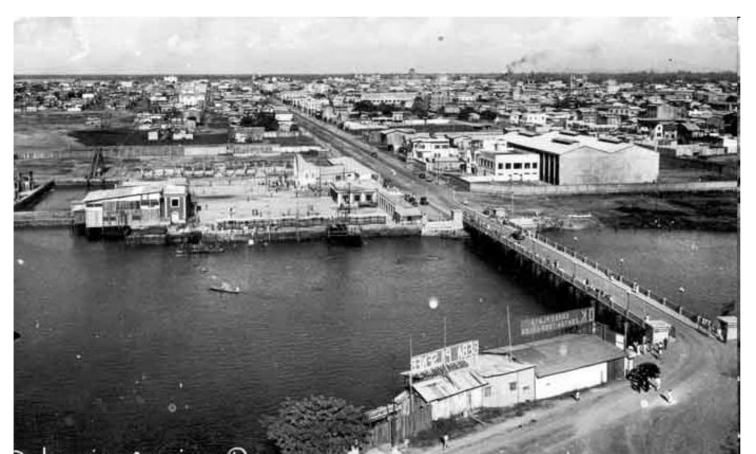

(b)

Figure 3. Chronological data collection of Guayaquil [2]. (a) View towards the downtown: old baths of the estuary between 1862 and 1876, divided into two sections, the left one for women and the right one for men; (b) View towards the downtown in 1935: Cinco de Junio Bridge and the American Park Spa are highlighted.

The first phase of the project widens the sidewalk that borders the university campus, turning it into a continuous corridor with green urban infrastructure connecting it with its adjacent spaces, a series of sidewalks, and waterfront parks (Malecón del Salado waterfront park of Guayaquil University, Guayarte Project, and the waterfront park of Catholic University Santiago de Guayaquil). Historically, they have been kept disconnected (See Figure 4). In this way, the current perception of scattered university buildings will shift to one of a unique and broad "integrated campus", which is sustainable, resilient, inclusive, safe, and participatory in consonance with the urban area of the city that shelters it. 


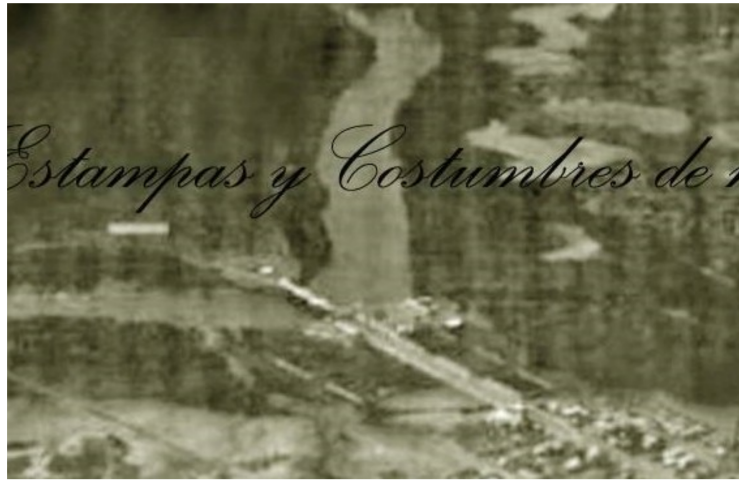

(a)

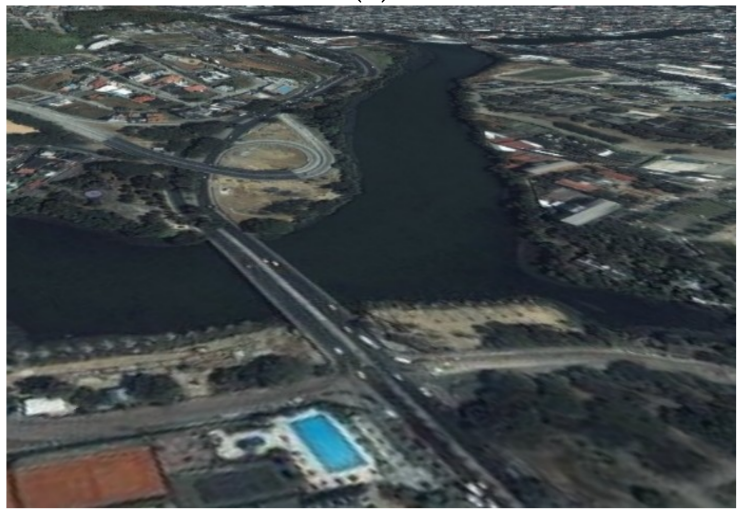

(c)

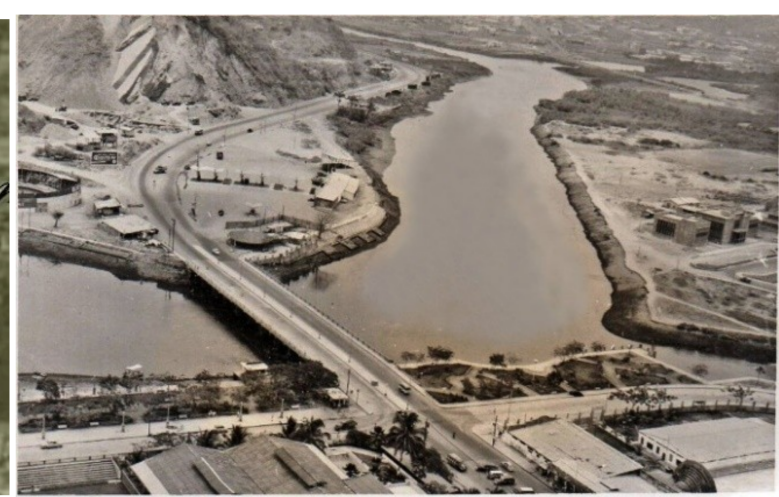

(b)

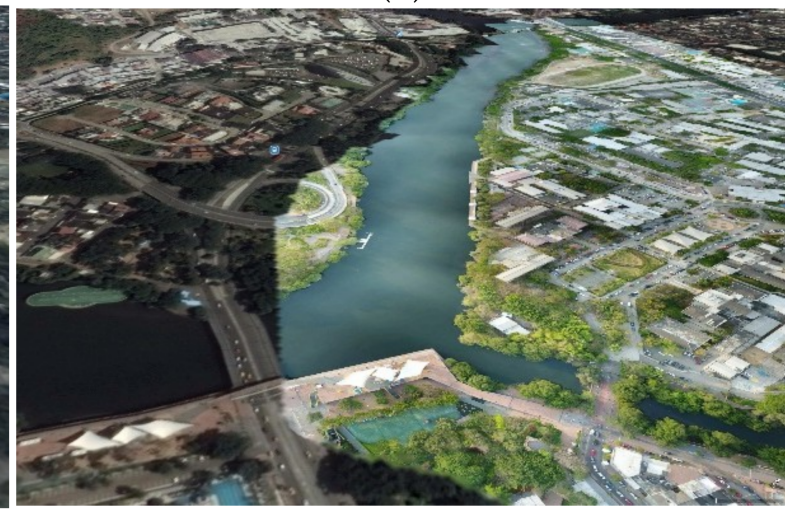

(d)

Figure 4. Chronological data collection of Guayaquil [2]. (a) Campus Salvador Allende, 1922; (b) Campus Salvador Allende, 1958; (c) Campus Salvador Allende, 1979; (d) Authors' elaboration of the current situation of the Campus Salvador Allende, 2018.

According to the National Institute of Statistics and Census report (INEC), until 2012, Ecuador had an average of $4.69 \mathrm{~m}^{2}$ of green area per inhabitant; the recommended minimum is $9 \mathrm{~m}^{2}$ per inhabitant, up to an ideal of $15 \mathrm{~m}^{2}$ of green area per inhabitant. The city of Guayaquil is part of the $95 \%$ of Ecuadorian municipalities with a shortfall in green areas. The INEC, in its May 2012 report of the VII population census and VI of housing, points out that Guayaquil has $1.12 \mathrm{~m}^{2}$ of green area per inhabitant, far below the level recommended by the World Health Organization.

Green infrastructure is a unique combination of economic, social, and environmental goals and benefits that requires an adaptable framework for planning, implementation, and evaluation [3] (See Table 1).

Table 1. Green infrastructure types vary widely based on system goals and motivation [3].

\begin{tabular}{cccccc}
\hline \multicolumn{5}{c}{ Green Infrastructure Types and Goals } \\
\hline Infiltration & Transportation & $\begin{array}{c}\text { Natural } \\
\text { Systems }\end{array}$ & $\begin{array}{c}\text { Stormwater } \\
\text { Reuse }\end{array}$ & Buildings & Other \\
\hline Permeable pavements & $\begin{array}{c}\text { Street } \\
\text { bumpouts }\end{array}$ & $\begin{array}{c}\text { Increased tree } \\
\text { canopy }\end{array}$ & Cisterns & Green roofs & $\begin{array}{c}\text { Nonstructural } \\
\text { measures (policy) }\end{array}$ \\
\hline $\begin{array}{c}\text { Infiltration } \\
\text { planters/planter boxes }\end{array}$ & $\begin{array}{c}\text { Permeable } \\
\text { pavements }\end{array}$ & $\begin{array}{c}\text { Constructed } \\
\text { wetlands }\end{array}$ & $\begin{array}{c}\text { Rainwater } \\
\text { harvesting }\end{array}$ & Blue roofs & Solar panels \\
\hline Bioretention areas & $\begin{array}{c}\text { Traffic calming } \\
\text { Bioretention }\end{array}$ & $\begin{array}{c}\text { Restoration of } \\
\text { wetlands }\end{array}$ & Cisterns & \\
\hline Bioswales & River estuary \\
Vegetated detention \\
strips
\end{tabular}


Most cities recognize that operations and maintenance are important steps in the accomplishing of their green infrastructure goals. Twenty-four cities have put in place a green infrastructure plan; nineteen of them included specific measures for maintenance. These measures include: providing resources for private landowners to maintain their green infrastructure, creating maintenance teams, and forging agreements with local businesses and homeowners to keep green infrastructure. Additionally, several cities require municipal agencies to inspect these green infrastructure projects on private land [3].

The Salvador Allende campus of the university has parks and gardens where a great variety of flora (fruit and timber trees, bushes, climbing plants, and palm and ornamental trees) are conserved and maintained; these make the campus more attractive, although it does not have an integral plan or management model of green areas that allows efficient planning and management for its maintenance and conservation (See Table 2).

As a consequence of the segmentation of the public space and an evident nonplanned intervention of the natural area and urban landscape limitations (See Figure 5), the idea emerged from the forums and interinstitutional liaison required to present the project to the Town Hall for financial support and execution.

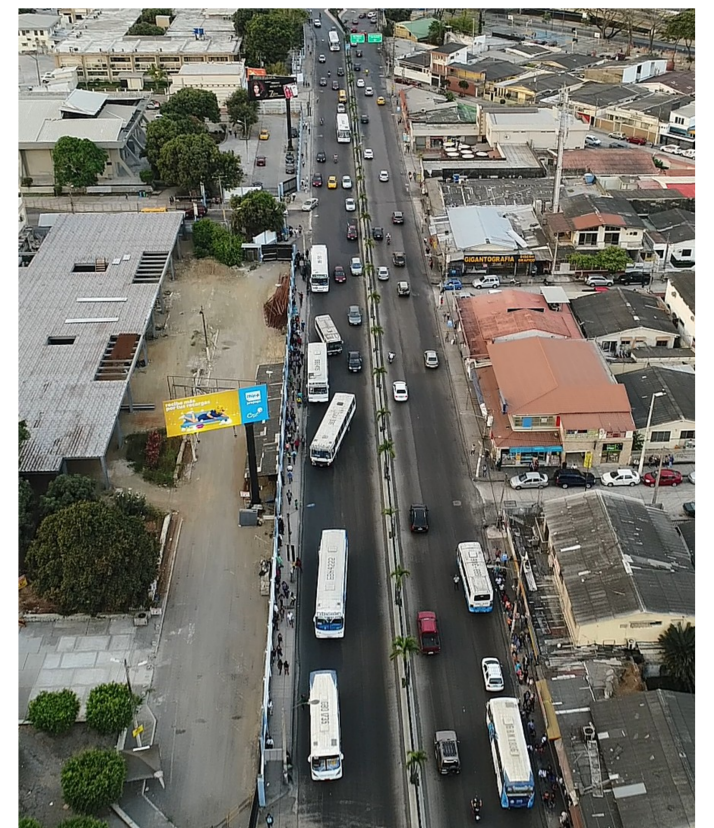

(a)

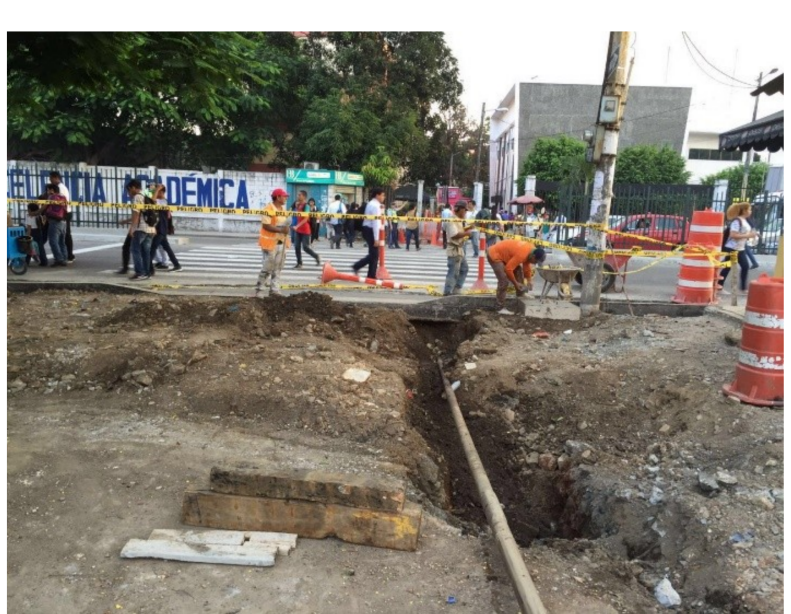

(b)

Figure 5. Current situation. Copyright the authors. (a) The metal fence can be observed in the central parterre; (b) Destruction of the trees to place a metallic post with a traffic light at the entry to the University of Guayaquil is observable in the background.

A city system's resilience in this sense is determined by its ability to persist and adapt to a new environment; a city's resilience reflects its ability to remain within given ecological thresholds, either in the existing environment or in the new environment. Here, changes in resilience reflect the evolution of a city system [4]. 
Table 2. Green areas inventory of the Salvador Allende campus, University of Guayaquil.

\begin{tabular}{|c|c|c|c|c|c|c|c|c|c|}
\hline Faculty/Dependency & $\#$ & $\begin{array}{c}\text { Total }\left(\mathrm{m}^{2}\right) \\
\text { Green Areas }\end{array}$ & Timber Trees & Fruit Trees & $\begin{array}{l}\text { Ornamental } \\
\text { Plants }\end{array}$ & $\begin{array}{l}\text { Palm } \\
\text { Trees }\end{array}$ & $\begin{array}{l}\text { Medicinal } \\
\text { Plants }\end{array}$ & $\begin{array}{l}\text { Grass } \\
\left(\mathrm{m}^{2}\right)\end{array}$ & Cane Plants \\
\hline Architecture & 22 & 4392 & 32 & 53 & 505 & 30 & 5 & 650 & 0 \\
\hline Administration \& Management Sciences & 10 & 0 & 8 & 30 & 232 & 6 & 1 & 0 & 0 \\
\hline Economic Sciences & 13 & 1340 & 29 & 19 & 532 & 23 & 10 & 467 & 0 \\
\hline Mathematics & 4 & 504 & 0 & 18 & 214 & 0 & 0 & 235 & 0 \\
\hline Main Administration & 8 & 700 & 0 & 6 & 157 & 25 & 23 & 565 & 0 \\
\hline Main Administration Front Park & 2 & 505 & 14 & 7 & 457 & 19 & 0 & 20 & 0 \\
\hline Medicine Auditorium & 6 & 796 & 5 & 11 & 92 & 2 & 0 & 0 & 0 \\
\hline Medicine-Obstetrics & 7 & 324 & 0 & 10 & 114 & 2 & 0 & 15 & 0 \\
\hline Medicine & 24 & 3880 & 14 & 84 & 865 & 26 & 1 & 406 & 0 \\
\hline Odontology & 12 & 805 & 7 & 8 & 52 & 15 & 0 & 0 & 0 \\
\hline Psychology & 6 & 2561 & 8 & 30 & 473 & 11 & 1 & 80 & 0 \\
\hline Law & 15 & 1254 & 10 & 14 & 581 & 23 & 4 & 221 & 0 \\
\hline Philosophy & 16 & 700 & 18 & 5 & 254 & 107 & 5 & 0 & 0 \\
\hline Professor's Association & 4 & 348 & 5 & 6 & 294 & 13 & 0 & 275 & 0 \\
\hline Agricultural Sciences & 10 & 557 & 12 & 16 & 207 & 32 & 0 & 0 & 50 \\
\hline Chemical Engineering & 20 & 2025 & 38 & 69 & 418 & 26 & 0 & 670 & 0 \\
\hline Chemical Sciences & 12 & 1608 & 10 & 26 & 614 & 72 & 1 & 1298 & 0 \\
\hline University Works & 4 & 405 & 2 & 5 & 90 & 0 & 0 & 140 & 0 \\
\hline Fixed Assets and Maintenance & 4 & 272 & 4 & 23 & 64 & 2 & 4 & 200 & 0 \\
\hline Physical Education & 12 & 8873 & 15 & 41 & 266 & 5 & 2 & 6602 & 0 \\
\hline Student Welfare & 9 & 240 & 3 & 11 & 278 & 2 & 8 & 27 & 0 \\
\hline Rufilli Lab & 7 & 1045 & 1 & 25 & 164 & 0 & 2 & 0 & 0 \\
\hline Central Small Square & 10 & 570 & 14 & 0 & 41 & 19 & 0 & 500 & 0 \\
\hline Park and Roundabout & 3 & 2233 & 20 & 7 & 2068 & 32 & 35 & 1359 & 0 \\
\hline Ecological Park & 1 & 1038 & 12 & 23 & 100 & 26 & 0 & 0 & 1200 \\
\hline Ecological Student Park & 1 & 1510 & 36 & 0 & 29 & 12 & 0 & 0 & 0 \\
\hline Associations & 6 & 1183 & 19 & 38 & 27 & 2 & 0 & 0 & 0 \\
\hline TOTAL & 248 & 39,667 & 336 & 585 & 9188 & 532 & 102 & 13,729 & 1250 \\
\hline
\end{tabular}


The Delta Project was formulated as an applied research project and approved by the University Council in 2017. It is integrated by research professors and students that belong to different academic faculties, whose main objective is to carry out the urban architectonic study of a sustainable campus for the University of Guayaquil; a living lab integrated with the public space, to be developed in two phases (See Figure 6).

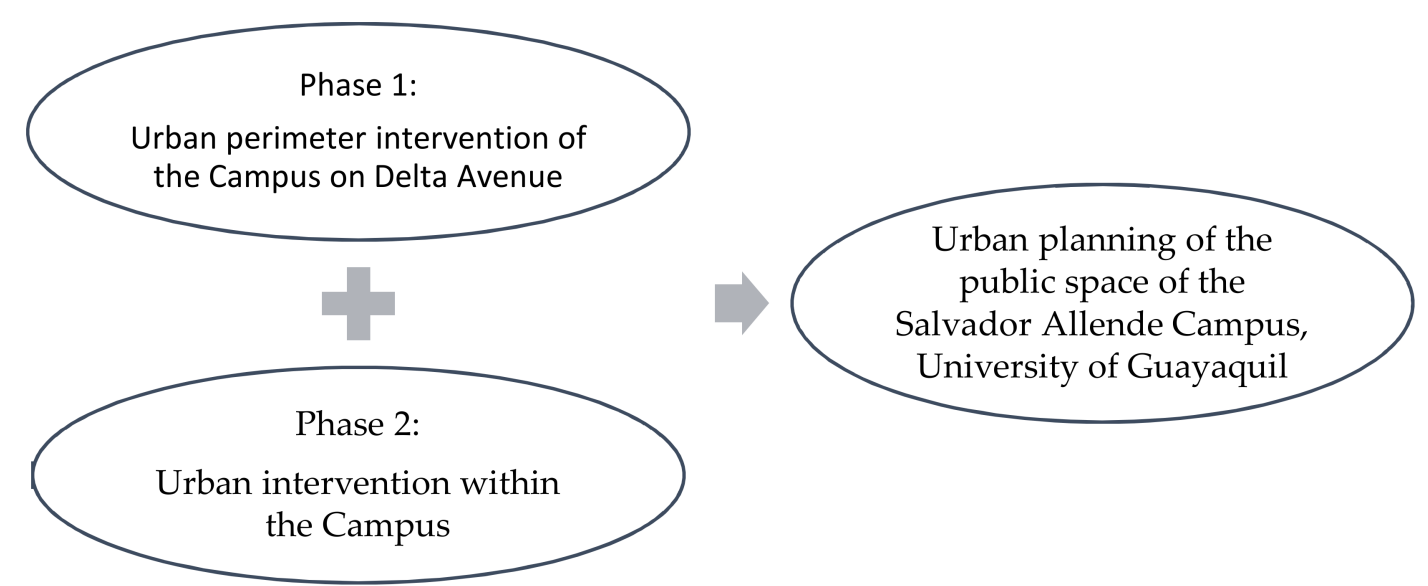

Figure 6. The first stage of the project is presented in this paper. See Appendix Figure A9.

\section{Materials and Methods}

The issues of sustainable resource management have been addressed in several international forums, from the report on growth limits developed by the Rome Clubto the update of the same report in 2012 [5], which in general terms, address the optimal management of resources in an environment of finite resources of the planet, considering the correct administration and use of technology as part of the way that could help humanity to survive in it.

\subsection{General Sustainability Guide}

\subsubsection{Sustainable Development (SD) in University Education}

Higher education is fundamentally key to a sustainable future; it has the necessary tools to develop new ideas and an active society that participates in experimentation for sustainable living. Universities have a moral obligation to work towards sustainable societies, focused on environmental degradation, threats to society, production, and sustainable consumption for them and for future generations. Leaders have the opportunity and responsibility to prepare professionals focused on interdisciplinary collaboration and cooperation, with high values of conscience, knowledge, skills, and values, that help to transform their places of work, society, and the place where they live, becoming responsible global citizens. Higher Education Institutions (HEIs) [6] must work as a fully integrated community (See Figure 7) that models social and biological sustainability in itself and in its interdependence with local, regional, and global communities, where students learn from everything that surrounds them.

University communitive initiatives to promote SD, such as statements, letters, associations, conferences, and so forth, could provide guidelines on how to integrate sustainability into the university system. Collaboration with other universities, making SD an integral part of the institutional framework, life experiences on campus, and "educating educators" are key elements that must be systematically integrated into HEIs to provide learning and educational value, as well as a race of the participants in the transition to the SD, thus guaranteeing the SD as the "gold thread" throughout the university system [5]. 


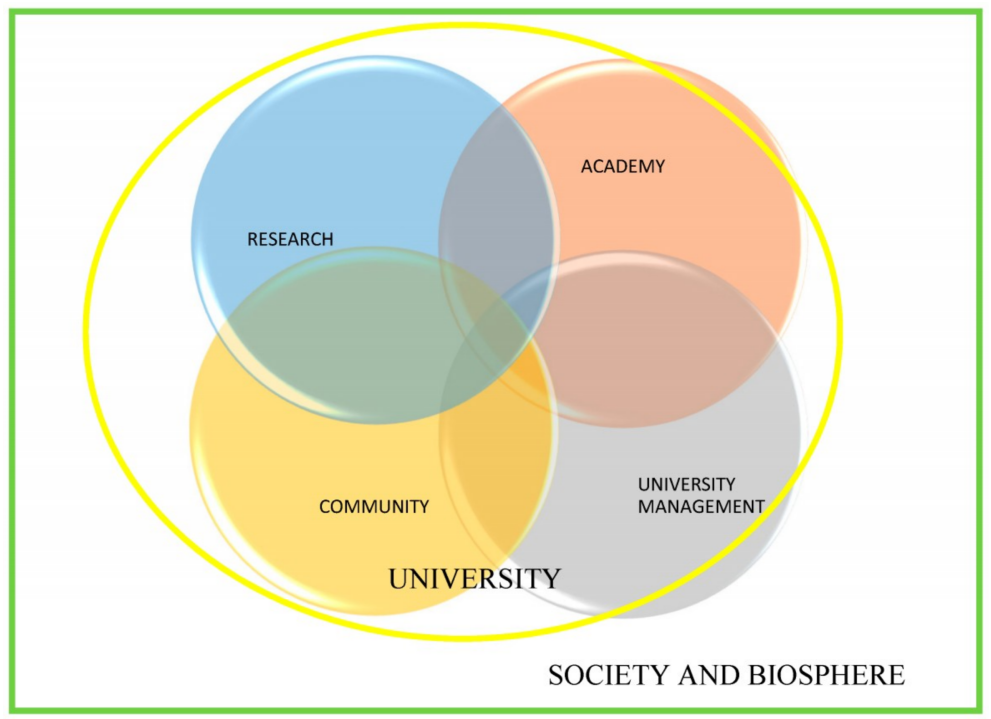

Figure 7. Higher education modeling sustainability as a fully integrated system [6].

\subsubsection{How Can Universities Achieve Sustainable Development?}

According to some authors [7], the sustainable universities should have the following characteristics: a bidirectional, interactive, and student-centered learning process, with a strong emphasis on critical thinking skills; a high degree of importance in conducting interdisciplinary and scientific research; social orientation of problem solving in education and research, where students are able to deal with the real problems and uncertainties associated with the future; creation of networks that can take advantage of the varied experience throughout the campus to share resources efficiently and meaningfully; and leadership vision responsibilities and rewards that promote the change necessary for the long-term transformation of the university by responding to the changing needs of society.

The strategies of seven universities around the world were compared [7] to identify the key aspects of its transformation towards sustainability, the ideal characteristics of the sustainable university, and the promoters and barriers in the transformation (See Table 3).

Three interactive dimensions (framework, level, and actors) were distinguished in this process of change. The framework dimension $(\mathrm{F})$ is related to intensive interactive changes in culture, institutional structure, and technology (the means to meet the needs). The level dimension (L) describes the change that is required. Finally, the dimension of actors (A) refers to people involved in the transformation process. The lack of an incentive structure to promote changes at the individual level is mentioned as the main barrier to overcome, and the presence of "connectors" with society, the existence of agencies and coordination projects, and the availability of funds are presented as keys to the progress of sustainability. A common feature is the declaration of transdisciplinary and interdisciplinary strategic objectives (See Figure 8).

As a strategic objective, as well as establishing and supporting networks of experience within universities, the establishment of connections with society is presented as a growing trend. 
Table 3. Internal and external barriers and promoters in the universities for the change towards sustainability.

\begin{tabular}{|c|c|c|}
\hline \multirow{4}{*}{ Barriers } & \multirow{3}{*}{ Internal } & $\begin{array}{l}\text { Academic freedom: Individual decisions about the best way to achieve research and } \\
\text { education objectives; it is difficult for an administrator to propose changes and achieve } \\
\text { consensus among groups of teachers at any level. }\end{array}$ \\
\hline & & $\begin{array}{l}\text { Incentive structure: Lack of recognition and compensation to teachers and staff involved } \\
\text { in the transformation of the university. }\end{array}$ \\
\hline & & Conservative administration. Lack of desire to change. \\
\hline & External & $\begin{array}{l}\text { Pressure of the society: Lack of demand on the part of society, of the desired characteristics } \\
\text { of graduates, and research for their development. }\end{array}$ \\
\hline \multirow{7}{*}{ Promoters } & \multirow{5}{*}{ Internal } & $\begin{array}{l}\text { Champions: They are the innovators or defenders of sustainability, who can be important } \\
\text { agents for change. By failing to provide them with institutional support to fuel continuous } \\
\text { work, universities run the risk of losing their most valuable supporters. }\end{array}$ \\
\hline & & $\begin{array}{l}\text { Visionary Leadership: Leaders with appropriate assignments and responsibilities, who } \\
\text { promote cooperation and collaborative efforts instead of interunit competition. }\end{array}$ \\
\hline & & $\begin{array}{l}\text { Connectors: These are the networks or groups of interdisciplinary research people that } \\
\text { come through the university to include a critical mass of actors on the campus, who can } \\
\text { interact between departments or with society in general. }\end{array}$ \\
\hline & & $\begin{array}{l}\text { Size: The complexity of the organization (more than } 10,000-12,000 \text { students) can reduce } \\
\text { the possibility of rapid transformation. }\end{array}$ \\
\hline & & $\begin{array}{l}\text { Sustainability Coordination Unit: Its creation is important to keep the process of change } \\
\text { alive and distribute responsibility. }\end{array}$ \\
\hline & \multirow{2}{*}{ External } & $\begin{array}{l}\text { Pressure from similar institutions: Pressure from peer institutions or top-level universities } \\
\text { can serve as examples to promote change. }\end{array}$ \\
\hline & & $\begin{array}{l}\text { Sources of financing and availability of employment: External financing through } \\
\text { corporations or government agencies willing to pay for sustainability-oriented research, } \\
\text { and employers that require graduates with sustainability strengths. }\end{array}$ \\
\hline
\end{tabular}

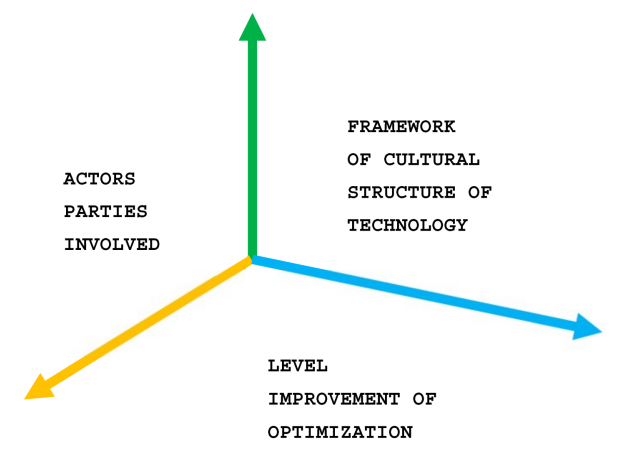

Figure 8. Framework, level, and actors (FLA) approach: three dimensions of change interaction to achieve sustainable development [8]. This figure shows the important interaction among the actors or participants involved, the framework structure of the living lab, and the optimization of the project.

Interconnecting sustainable development as a concept, within and between different disciplines and schools, adapted to its specific nature, could help universities move towards a more balanced, synergistic, transdisciplinary, and holistic academic system, thus helping graduates contribute in better ways to the development of more sustainable societies [9].

The School of Architecture has not been left out of the evolution towards a dependence on nonrenewable energy resources; it has had a limited evolution due to not only the restrictive framework of the survival of the traditional city, but also the technical elements that sustained it. The set of elements that connects architecture to the territory, and especially with the city, have hindered its articulation in the new productive system [10]. The material which the visible city is formed with has endowed this transformation with inertia, but at the same time, as it has been continuously stressed to adapt. The new 
city, the new buildings, the new forms of production of materials, the changes in the organization, and the end of the production process of architecture are decisively altering the traditional technical systems to start a different architectural technology with an absolute redefinition of its conception. At present, traditional materials such as stone, wood, or earth, which were examples of closed material cycles, have altered their production systems. The traditional technical system [10] in architectural technology is affected mainly by the transfer of production materials to the industry, aligning with the work and fighting against the physical location of the architecture that limits this transfer.

Sustainability in the environmental building design is a key factor to address in response to the limited availability of resources, ecological deterioration, and climate alteration. In order to respond to the demands of the current market, a pedagogical methodology must be developed to overcome existing educational and professional barriers and act as a communication platform that facilitates the transfer of knowledge between the construction science related to sustainability and creative design in the architectural curriculum [11].

Students should be encouraged to emphasize reflection and critical self-assessment and should be able to balance the integrity of design and environmental responsibility, considering environmental design as a basic, essential, and integrated requirement of the design exercise itself. A good theoretical base is essential in teaching; however, it has to be supported by empirical knowledge and evidence-based learning to understand how different principles can be applied in practice and by analytical tools and simulation techniques that can facilitate the testing and comparison of different hypotheses and make performance forecasts from the early stages of design. Skills such as concrete experience, reflexive observation, abstract conceptualization, and active experimentation could help the development of critical thinking, which together with interdisciplinary paradigms, are the basis of education for sustainability [11].

The achievement of a "sustainable" curriculum truly oriented to design is still difficult to achieve, due to the nature of the theme itself. Most of the time, design study projects are complex and time-consuming such that students are not able to do it in a semester while reaching a level of mature and deep analysis that includes awareness and integral implementation in the design of technical and environmental mandates [12].

Cognitive discrepancies are not only related to students, but also to their study tutors, who rarely master the technical aspects of environmental design, while academic staff teaching technical subjects are often not associated with the study team design [13]. Architects generally employ a solution-centered teaching strategy rather than a problem-centered design development approach, where students focus more on achieving a desired result than on a critical investigation of the complexity of the problem they face, favoring the acquisition of information and hindering the development of critical thinking.

\subsection{Living Labs as a New Method of Scientific Production in Higher Education}

According to [13], the proposed framework is used to lead the development of a database in order to collect key data about a Living Lab. It is designed to be a supportive instrument over the whole lifetime of a Living Lab_from initial planning stages, through monitoring phases, through to its final closure and reflection on the lessons learned. The seven categories for data collection cover all of the different stages of the Living Lab and allow monitoring on whether outcomes and impacts set out in the initial stages have been met, and how partnerships, participants, cocreators, and organizational structures have evolved. The seven data collection categories are (See Figure 9):

- General: a summary of the Living Lab location, key contacts, status, timelines, and budget

- Scope: the problem being addressed, historical details to the problem, the context, and the key sustainability 'theme' being addressed

- Participants and cocreators: different stakeholders and ways in which they are engaged

- Organization: leading organizations, partnerships, potential risks 
- Outcomes: anticipated (and actual) sustainability outcomes in relation to the problem being addressed, as well as anticipated (and actual) educational, research, and engagement outcomes

- Impact: wider impacts outside of the Living Lab boundaries

- Reflection and review: evaluation of the living labs' products and processes

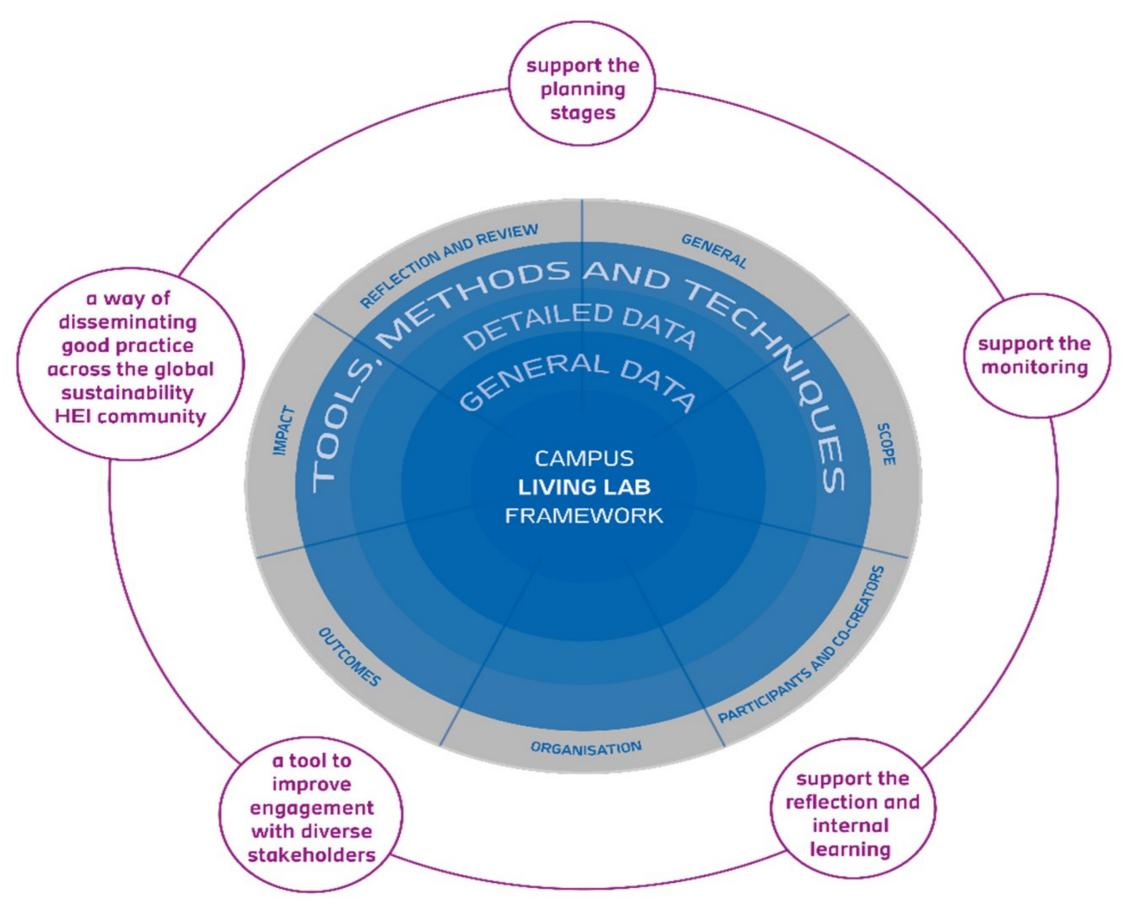

Figure 9. Campus as a Living Lab Framework design with its seven categories, five potential values, and three levels of detailing and application [13].

In this sense, we must promote horizontal systems to create a collective based on collaboration, so that we must learn to collaborate, to promote the collective versus the individual, and to achieve shared success and distributed merit. The development of transdisciplinary strategies is not only of undoubted interest for contemporaneity, but also brings very interesting values to collective work. When an excessively homogeneous community is created, it produces flat ideas. The article "Teaching Sustainability through Living Labs in Architecture: The case study of the UPC-LOW3 prototype solar house" bases its content on the LOW3 Living Lab, defining it as a project in execution, which aims to innovate in education for sustainability through user-centered research and collaborative learning within the university campus. The author indicates that specific disciplinary knowledge should be taught by adopting a holistic, transdisciplinary approach to the environmental, economic, and social aspects of sustainability. The analysis aims to leave its results and lessons learned as examples for similar activities in other universities [14].

Dynamic networks could generate laboratories that investigate in a distributed and connected way, going beyond the communication that technology facilitates. Not only should it be an organism with different coordinated devices, but also we must reinvent the way we investigate, overcoming separation and individualized concentration in order to seek unique and innovative results that exceed the sum of the parts [15].

Collaboration is more beneficial and difficult to handle, since the speed at which it occurs makes it impossible to control all the necessary dimensions. However, it is not enough to manage teams that sectionalize information too much, but rather, it is necessary that the components work together as a single body, so that the results benefit from an authentically collaborative process.

According to [16], "Innovative Models of Administration and Public Management: Towards the Emergency of New Paradigms", three basic characteristics of managerial processes are proposed. 
(....). Innovation in Public Administration is characterized by the publication of numerous works in recent years (Maddock, 2009, Mulgan, 2009, Potts, 2009, Kohli and Mulgan, 2010, Moore and Hartley, 2010). This is reflected in the concept of innovation in the public sector as well as the plurality of existing "dispersed" approaches and the "polysemic and elusive" character (Ramirez-Alujas, 2012: 7), although it also notes a lack of empirical studies, such as consequence of "disciplinary myopia" (Windrum, 2008). Other authors add elements related to the practices carried out by the organizations in order to improve the product or service they provide, characterized by the ideas of Change (radical change and impact), New (something new for the organization in question; it is not only a "good idea") (Audit Commission, 2007), but also refers to the introduction of a social dimension, adding that innovation in the public sector and new ideas should be able to improve the operability of institutions and raise the standard of living of a society. Transformational and direct innovation is linked to changes in the structures of public management adding new ideas and practice of transparency, accountability, citizen participation and optimal use of resources. Its empirical observation is a complex task given the intermingled link between the values and their connection with the options of a political nature (external order), as well as the existing power relations within the public administration (internal order). In the external order, it manifests itself its relationship with the citizens in the process of co-creation, co-formulation, co-evaluation of public policies being the central element that distinguishes innovation from change in the impact of its process with the predominant paradigm of the organization. Nowadays, a large part of these new ways of public management involves the idea of Open Government. (Ramírez-Alujas, 2010, 2011)

Innovation in administrative processes (incremental innovation) usually originates in practice; the implementation of the so-called "Best Practices 12" is not a new phenomenon, but has its origin in two assumptions: on one hand, due to the innovative processes introduced in business management and in organizations (models of motivation, personal development, achievement of objectives), and on the other, as a consequence of citizens' demands and the consequent crisis of legitimacy of the public administration that manifested itself in and since the decade of the 1990s. Public administration suffered a constant deterioration, in which the need to introduce good practices became an urgent task. The proposals derived from the good practice have served to apply management proposals in an experimental way, as has happened in various municipalities and higher education institutions in Latin America.

Not all "new" approaches and trends are truly new or innovative. Some are merely applied practice to solve very specific problems in the short term, derived from broader frameworks for reformulating public management, such as adaptations of the New Public Management. These are specific actions adapted to information and communication technologies (ICTs) and can support the initiation of new models and forms of public and social management, whose possibilities and doubts have already been exposed [17]. Mention must be made of the planning and management actions and strategies aimed at the economic sphere, which, although they are not new models for reformulating public administration in its entirety in a broad sense, are more practical, or less successful and innovative, and that have been applied for some time successfully and that are limited to different levels or specific fields of general and local public administration, such as the case of the Common Assistancy Framework (cAF).

\subsection{Operational Sustainability Guide}

The complexity of the problems meant fac an enormous effort to redesign the existing processes, discarding old methodologies and creating new systems that will make it possible to attain the new objectives demanded for a contemporary environment. Therefore, new structures must be built so the research can continue and be able to bring the future closer.

In this sense, the standardized and enclosed structures should be substituted for others which are more flexible and open, favoring the evolution of individual work towards a collective effort. The Delta 
Project does not respond to classic research standards since the campus is a model of cumulative results; there is no evidence of integral planning processes.

The inductive research process began by defining the pedestrian road system, with the collection of traffic accident records along the Kennedy and Delta Avenues. It was necessary to know the streets' geometric characteristics and the volume of the vehicular and pedestrian traffic that circulated along Delta Avenue. Pedestrian traffic is distributed on both sidewalks, one of them adjacent to the university and the other adjacent to the Bolivariana district, where most of the complementary services which are required by the students, such as restaurants or stores selling stationary, are located. It is therefore necessary to raise the activities' plan and citadel's soil usage in order to integrate it to the zone's functional dynamics.

On the other sides of the campus, the Guayaquil University is surrounded by a system of spaces and natural estuaries with low or null accessibility. Even though the municipality has control over the riversides, the works that have been implemented were not integrated into the students' lives. Pedestrian systems are not connected to the natural systems, which requires research to identify the species that configure these natural and green areas of the campus and to know the projection for pedestrian movement within a growth plan.

As indicated at the beginning, the physical planning process has been incremental and slow, requiring an upgrade infrastructure which has taken more than 60 years. It was indispensable to know or to evidence the planning system and the actions within the campus by various departments in areas such as road tracing, soil usage, grouping of buildings parking lots, development areas, existent necessities, future necessities, and so forth.

Another guiding aspect in the research process was the city's planning system, adopted by the local Town Hall. The municipal projects in the study zones were studied, especially the impacts of Project Delta connected to the rest of the city, emphasizing the urban infrastructure such as roads, parks, and others that are close to the university.

In order to address these tasks, it was necessary to connect these four big systems in a dynamic way, requiring the adoption of a methodology that allows building fast and integrated knowledge, (See Figure 10). Using research and formulating a collaborative investigation system in a living-lab environment, thus granting a higher student participation as well as teacher participation. This lab was shaped by students of different semesters, from the beginning to the tenth, whilst the professoriate was comprised of the project director, general adviser, and some other experts.

The main concept was focused on the users (the students) emphasizing the thought of design where the students learn and exchange their knowledge, developing new ways of working. They develop new designs and new work mechanics, and they work together for the development of their territory.

The interest which the project generated in the university allowed this methodology to be adopted, with the selection of students with some expertise, as well as the configuration of expert groups of teaching staff or external professionals that would communicate with each other during the dynamic interdisciplinary forums. 


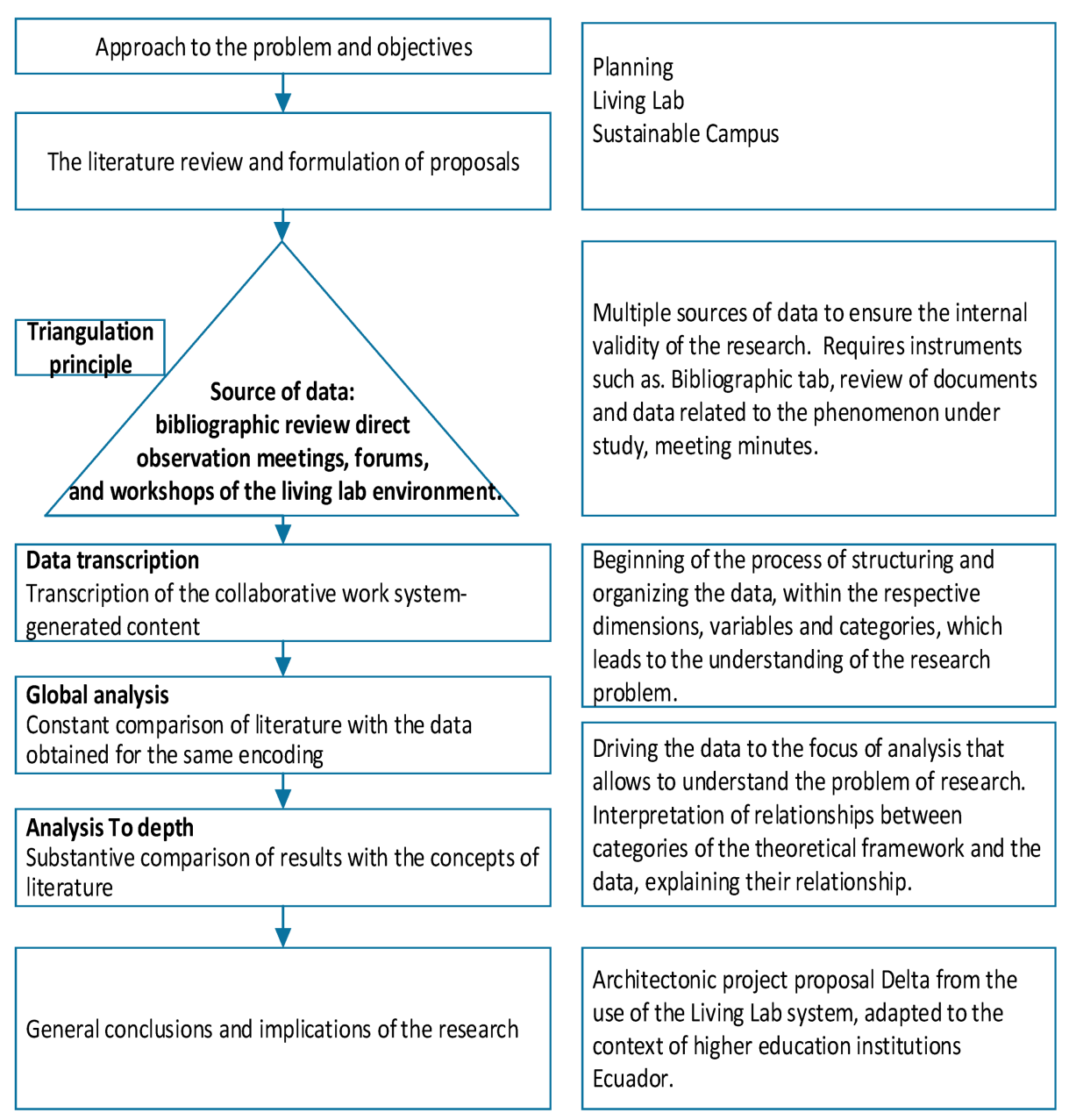

Figure 10. Applied methodological structure.

2.4. The Collaborative Research System in a Living-Lab Environment Needs to Be Developed in Four Well-Defined Process Protocols

The Standardized Physical Planning Protocols, The knowledge integration protocols, The Professionalization and the management of the project (See Figure 11).

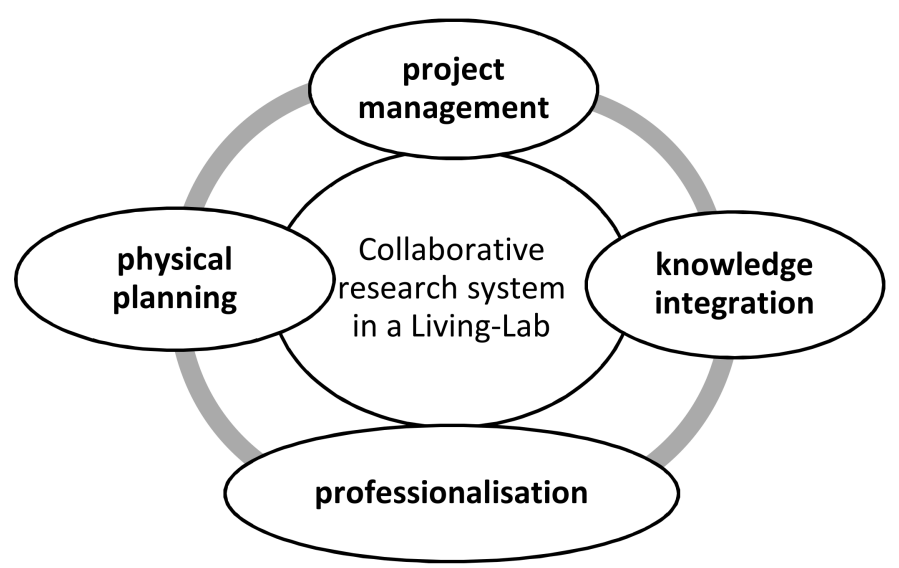

Figure 11. The collaborative research system in a living lab. Copyright the authors. 


\subsubsection{The Standardized Physical Planning Protocols}

The Standardized Physical Planning Protocols must be addressed to a big number of simultaneous processes, unlike the approach of Delta Project, that emphasizes an inductive system, beginning from the flow system (or, rather, the pedestrian-road system), then a system of natural spaces and estuary, so they could finally mix together with the physical planning system and the city's planning system.

The most general tools for this kind of project were the Urban Regulations of Public Spaces (which were developed by Jan Gehl), the Municipal Urban Regulations, the Ordinance of the Land Use Plan, the Traffic Rules, the Territorial Arrangement Planning's annexes $5 \mathrm{a}$ and $5 \mathrm{~b}$, and the AASHTO standards; there were even reviewed pedestrian simulators such as SIMULEX, PED go, Legion, Exodos, Gridflow, but in the end, it was concluded to use the VISSIM Simulator, polls, ecosystem nomenclature, especially the link between social and natural sciences of Eugene P. Odum, and the EPA's Handbook of Urban Runoff Pollution Prevention and Control Planning.

In the physical planning area, the project had several technological tools that allowed researchers to obtain first-hand onsite information using a drone.

\subsubsection{The Knowledge Integration Protocols}

The knowledge integration protocols allowed students in the lab to integrate different types of knowledge simultaneously in one place, while the professors' forums enabled the students to integrate this knowledge while they worked, differentiating from the academic speech which usually proposes a pyramidal classes' system in the different classrooms.

The protocols used required a mapping of possible knowledge blocks that the project should support, from the blocks of STEM (Science, Technology, Engineering, and Mathematics) to the blocks of Humanities. This combination would allow a quick resolution of problems.

The first protocol defines the modality of student participation. The time used in the project was considered as part of the preprofessional work experience which all undergraduate students must complete. The student tasks were divided into different activities, which allowed the project to be divided into parts, from the identification of the problem, the establishment of solution paradigms, the formulation of concepts to solve the problem, and the updating of knowledge about the project, to the implementation of a work method for the coupling of the software that the project would use; then, each student was responsible for a development block, which was then submitted to the integral refining committee. The participation of the students in the project was from different faculties.

\subsubsection{Professionalization}

Professionalization is another essential protocol which enables a person to become sufficiently academically knowledgeable, practical, skillful, and competent to be able to perform a paid job (self-employed or employed by others). These protocols will allow the design standards demanded by the professors to be comparable to those required in the professional market. The professors who joined the laboratory had extensive professional training, having carried out many professional projects, and this would guarantee that the students would integrate high design standards in the proposal, which would make a big difference with teachers who did not have professional experience.

The most relevant protocols were created by professionals in specialized forums and interdisciplinary forums. Counting with the participation of students, the key forums considered software, public space, ecology, green areas, transit and transport, art, budget, infrastructure, networks, and facilities. The practical action of the professionals in the design allowed the students to find answers with high standards. The forums could be done inside or outside the university; for instance, the Faculties of Mathematics and Agricultural Sciences, botanical garden, the planning department of the university, the paving stone companies, and so forth have created and participated actively in different forums, getting great results. 


\subsubsection{The Management of the Project}

The management of the project is the last protocol proposed, that began with discussions in the different governmental levels of the university: the students, the community, the press, the city, the region, and the country. Through that management, principal agents were identified that would achieve the required level of feasibility for the project's execution; the project was never considered as an academic project from the outset, as its main objective was to be deemed sufficiently viable to be implemented.

The main proposed tools included:

- The consultation and student community agreements process with local residents and businesses

- Press briefings

- Presentation of the project to several authorities, especially to those of the Town Hall

- Presentation of the project in international conferences and workshops to coordinate collaboration with universities and other partners.

\section{Results}

\subsection{Physical Planning}

The project was concluded with the urban proposal, the road proposal, the pedestrian proposal, the proposal of the taxonomy of the trees, the proposal of lights, and the proposal of higher steps and level (See Table 4). These proposals were based on multipurpose surveys, vehicular and pedestrian traffic counts, national and international technical standards, INEN, American Association of State Highway and Transportation Officials, streets and roads manual of the public works ministry, and the Ecuadorian construction code.

Table 4. Contribution of public space for the Delta Project at Salvador Allende campus, University of Guayaquil.

\begin{tabular}{cccccc}
\hline Items & $\begin{array}{c}\text { Faculty of } \\
\text { Architecture }\end{array}$ & $\begin{array}{c}\text { Faculties of } \\
\text { Administration and } \\
\text { Medicine }\end{array}$ & $\begin{array}{c}\text { Faculty of } \\
\text { Dentistry }\end{array}$ & Total & Measure \\
\hline Existing trees & 26 & 22 & 8 & 56 & Units \\
Proposed trees & 27 & 61 & 12 & 100 & Units \\
Green area proposal & $1460.10 \mathrm{~m}^{2}$ & $990.87 \mathrm{~m}^{2}$ & $294.15 \mathrm{~m}^{2}$ & $2735.12 \mathrm{~m}^{2}$ & $\mathrm{~m}^{2}$ \\
Paving stones & $4565.73 \mathrm{~m}^{2}$ & $4137.37 \mathrm{~m}^{2}$ & $1152 \mathrm{~m}^{2}$ & $9855.10 \mathrm{~m}^{2}$ & $\mathrm{~m}^{2}$ \\
Individual Park Furniture & - & $9 \times($ module of $4 \mathrm{U})$ & - & 36 & Units \\
Multiple Park Furniture & - & $8 \times($ module of $12 \mathrm{U})$ & - & 96 & Units \\
Bus furniture & - & 6 & - & 6 & Units \\
Bikeway & - & - & - & $555.23 \mathrm{~m}$ & meters \\
Current enclosing meters & $180.24 \mathrm{~m}$ & $272.57 \mathrm{~m}$ & $134.50 \mathrm{~m}$ & $587.31 \mathrm{~m}$ & meters \\
Reform of the closing meters & $88.48 \mathrm{~m}$ & $149.47 \mathrm{~m}$ & $20.39 \mathrm{~m}$ & $258.84 \mathrm{~m}$ & meters \\
with the Delta Project & \multicolumn{5}{c}{}
\end{tabular}

A sample of the relevant section of the results is provided in Appendix Figure A1.

\subsection{Integration of Knowledge}

The preprofessional work experience played an important role; it is a binary indicator because it allows to measure the degree of effectiveness and participation of the students in the project; besides, it measures the collective participation in the resolution of the problems. Last reports or records of group and individual tasks were used to conclude that they were fulfilled to a level of $80 \%$.

Participants reached $80 \%$ of the learning goal, mainly through simultaneous knowledge (learning from different fields simultaneously). This analysis considers the teaching staff who formed part of the study, working in the multiple fields previously identified.

A sample of the relevant section of the results is provided in Appendix Figure A2. 


\subsection{Professionalisation}

Twenty-five forums were organized with the participation of 32 professionals from 7 specialized fields: technological, agricultural, ecological, urban, road, transit and transport, and pedestrian. Twelve interdisciplinary forums were completed. A sample of the relevant section of the results is provided in Appendix Figure A3.

\subsection{Project Management}

In this field, the participation with different parties was carried out through meetings with local business community and students, calls, and surveys, which were evidenced by photos and videos (see Appendix Figure A4).

The project "Think \& Eat Green @ School" is an example of participative management, involving schools and educational institutions, and by extension, the food system of the City of Vancouver. The project creates an experience of collaborative learning amongst stakeholders, university students and scholars, and health and educational institutions to a network of community-based and community-supported nonprofit organizations working on food and environment, linking farms to schools, city dwellers with farmers, and school cooks with successful green chefs, as well as creating links between restauranteurs, restaurant designers, gardeners, school authorities, teachers, and students [18].

The meetings with the university authorities were evidenced by photos and videos, concluding in the approval of the project by the University Council, having held meetings with the rector of the University of Guayaquil and deanships of each faculty regarding financial management, management of university works, direction of art and culture, and direction of green areas (see Appendix Figure A5).

The meetings with the Guayas Government were evidenced by photos and videos; the Project and the security problems were presented and exposed to its community, along with the need to create a sustainable campus, concluding in the assignment of a mobile community police unit. Now, the police elements are transported by bicycle inside the university campus (see Appendix Figure A6).

The meetings with the municipality were also evidenced by photos and videos, concluding in the allocation of the budget for the work, having held meetings with the local mayor, "Malecón 2000" and "Siglo 21" foundations, and the municipal transit authority (ATM) (see Appendix Figure A7).

The socialization and validation of the project in international events was undertaken to collect feedback and establish joint collaborations. In this case, the Delta Project was taken into account for the main conference in the workstation modality, also including the presentation of the poster on a technological park for the University of Guayaquil. A sample of the relevant section of the results is provided in Appendix Figure A8.

The press plays an important role, starting from an independent management and leading to the dissemination of the project in a massive way to public opinion that allows the empowerment and commitment of the actors involved in the project: the ones that finance, the ones that propose, the ones that study, and the users to whom the project was destined.

The press agents are the external equivalents who share and contrast information by taking statements from those involved, thus being an important link in interinstitutional coordination. At the same time, the population becomes aware of the results and benefits provided by the project.

\section{Discussion}

The broad objective of this project is to show that the School of Architecture aims to implement a strategy for the management of public space based on the use of four dynamic systems that interact, evaluate, minimize, project, and make feasible urban solutions. These are the physical planning system, knowledge integration system, professionalization system, and management system.

From the field of urban design, its response has been achieved to overcome the difficulties posed by traditional urban design standards, in terms of the revitalization of deteriorated urban areas, which 
has overcome the way of addressing the issues of urban revitalization. In the past, this was always oriented to physical planning from an academic dimension, and away from the profession. It can be said that public space was elusive for university pedestrians; existing pedestrian areas represented environmental risks, which were evaluated and minimized by implementing the strategy [19].

In general, the strategy consists of using new tools, which allows them to be joined, since in the academic field, they are used in an isolated and dispersed way. The only way to connect them was to use a new tool called the "living lab", a live operations laboratory, configured for students in different stages of their degree program who require professional internships. The production achieved in record time would not have been possible without the design of this living lab concept developed for the Delta Project.

The physical planning system, in general terms, is responsible for the design as well as the financial and regulatory variables. The system of integration of knowledge was responsible for adopting a scheme of knowledge clusters in situ; a different environment to that promulgated by the routine academic meshes. The variables of this system were shaped by the variables of fields of knowledge that were taught through of instructions of blocks of tasks. The professionalization system had an important impact, so much that it was introduced to the professionals and specialists in the evaluation processes, to minimize, project, and make the solutions viable. The variables of this system were established to implement the highest standards used in the professional market, suggested by the specialists, and configured by the variables of fields of knowledge with standards of design, programming, and costs. Many of the specialists who were part of the project were not necessarily academics. The management system was required for the implementation of actions for the resolution of the components, the processes, the availability of resources, the coordination of activities, the project to materialize, and the configuration of the variables of the student component, professionals, managers of the university, executives of the municipality, the community, the press, etc.

Other ways can be indicated to show that the systems adopted have allowed the necessary results to be achieved and the four levels of the process to be integrated: the associations of the affected or public actors for the public sector for public spaces, the integration of knowledge for professional practices, and the design strategies that are applied in the Delta Project area. All measures include aspects of the development and implementation of a sustainable approach.

The general approach that was adopted began with the integration of four key priority evaluations:

- Establishment of priorities based on the current risks presented by the current pedestrian conditions of university students;

- The natural conditions of public spaces;

- The direct participation of the actors;

- The design of the solution: to comply with all requirements in a sustainable manner, including environmental effects, space and available facilities, local perceptions, and other problems.

Subsequently, the second phase of the project will be implemented within the campus. Given that the river estuary (the Estero Salado) borders the campus to the west, a susceptibility analysis must be carried out.

Assessment of landslide susceptibility in urban areas could provide an important contribution to minimizing damage from natural disasters; it could be also used for planning and multiple hazard assessment [20].

It is therefore advisable, within the studies to be carried out in the field, to collect data on geological antecedents of the region. In the knowledge of the types of soil in the study sector, a thorough investigation should be organized to verify the incidence of this phenomenon in the premises where it will be built.

The karst collapse susceptibility map provides valuable information for land use planning at a regional scale, leading to the recognition and determination of the safe and nonsafe areas for urban development [21]. 
The susceptibility map can be used by the local authorities to guide the adoption of policies and strategies aiming towards sustainable urban development [21].

This work can contribute enormously to five essential aspects:

a. Increasing the public spaces of the city [22], since the local municipality lacks a policy of public spaces [23], a situation that is not foreseen in the land use plans, nor is it a component articulated in the Organic Code of Land Use.

b. Public spaces such as pedestrian areas are not registered in the Organic Law of Land Transport, Traffic and Road Safety, and are only in a very indirect way mentioned in articles 4 and 9 of the said law, when there must be a whole chapter dedicated to pedestrian areas and their relationship with the road system [24].

c. According to the results achieved, presenting a new way of teaching architecture and urban design [25], which goes beyond the traditional and routine education of the current mesh of subjects [26], so it would be advisable to reform the academic regime regulations established by the Council of Higher Education (CES), allowing an education of blocks of subjects in a design laboratory, which must be discussed in the Organic Law of Higher Education [27].

d. From the environmental point of view, urban ecological corridors are not part of the classification system for a healthy environment; regulations such as Book IX of the Unified Text of Secondary Legislation and other standards are only devoted to quality control of the resource, so that urban ecological corridors can be part of the environmental planning system, as elements that improve the life and health of people in cities, and these planning systems can be included in the environmental planning of cities [28].

e. It is necessary to emphasize that the sustainable development of the work was only reached when two institutions were intercepted to optimize the resources in the same project that benefits both the municipality and University of Guayaquil.

\section{Conclusions}

Creating sustainable and resilient urban relationships with the environment will entail a reimagining of those relationships. That reimagining will require that we improve our understanding of the dynamics of urban relationships with the environment across space and time. However, just as importantly, we must better understand our relationships with each other within and across domains of time, space, economics, and human organization [1].

The ecological corridor of the Delta Project is an urban rehabilitation project and its adequacy has depended on three key factors: the academic approach, the professional approach, and with a significant amount of urban management. The proposal consisted in proposing a corridor of public space for pedestrians, imitating the ecological corridors of the adjoining estuary with a participative environmental management. Agreements and alliances have been relevant to sustain conservation actions. The meetings and negotiations with public and private organizations, local communities, students, residents, merchants, research centers, botanical centers, universities, schools, owners, and authorities allowed to generate consensus about the importance of imitating the ecological corridor of the estuary around all the university campus, forming a circuit in the manner of a linear park endowed with walkways, native wooded areas, squares, bus stations, cycle tracks, and so forth.

The interactive work with the municipality, with the students, and with the local business community deepened the relationship needed to develop a pedestrian corridor that the university does not have, guaranteeing the right to public spaces and serving for the distribution of the student population to the internal and external areas of the university, in addition to ensuring the protection of biodiversity. For this purpose, surveys and technical and administrative consultations were carried out.

The limitations of the participatory approach were given as follows: Sporadic student attendance due to the time limit: this could be solved by the implementation of $240 \mathrm{~h}$ of preprofessional practice that must be approved to obtain the title of "professional"; Limited attendance of the investigators 
attached to the project, due to the absence of common schedules and the time allocated for investigation, which could not be greater than $7 \mathrm{~h}$ per week in the case of the director and a maximum of $5 \mathrm{~h}$ for the other members of the Project. To resolve the situation, the administrative and financial management was requested to support a full-time researcher for the purpose of coordinating progress with the students and consolidating the information that is produced daily in the space destined as a workshop. As a project whose financing and construction is provided by the Municipality of Guayaquil, it was presented for the second time to the higher academic college for approval of the initiation of the interinstitutional agreement with the municipality. Although there were no criteria against the project, a political variable appeared in this space, resulting in the voting support of the members who support the current administration and the abstention of the other members. As for the coordination with the Municipality of Guayaquil, since it was presented, the project was approved and supported by the mayor, who ordered the coordination of the project with the foundations 21st century, Malecon 2000, the Director of Public Works, and the Municipal Transit Authority. On the way, there were found different viewpoints with the Municipal Transit Authority; in our case, the project focused on pedestrians, and sustainable mobility had to be supported by a mobility policy that favors the vehicle. In this case, the mayor and the foundations were supported by the benefits of the project to generate a sustainable development model, and it was finally approved.

The results obtained pointed to several fronts:

On the academic front, a different approach to the teaching of urbanism is proposed through the living labs, which integrate knowledge in a group of subjects and not in isolation, as stated in the current curricular meshes of Ecuador; in the same way, this form of teaching and learning could well be applied to research and degree projects; such a recommendation affects the reform of the Academic Regime Regulation (RRA) proposed by the Council of Higher Education of Ecuador. This would imply a substantial reform in the form and substance of the presentation of the curricular meshes. Clusters of comprehensive knowledge fields were included, from the use of basic software to draw and make vehicle traffic counts, to the use of specialized software for the simulation of pedestrian and vehicular traffic, as well as climate simulators, the use of drones for planning and photography in real time, plant taxonomy, reforestation practices, artistic guidelines, budgets, soil studies, site visits, population needs, and so forth.

From the urbanistic point of view, it is concluded that the municipality could adopt a second front. In a systematic way, the criteria of an integral pedestrian corridor for the development of public spaces in the form of an ordinance will be considered strategic within the units of the land use plan, given that it corresponds to existing facilities at the time of execution-in particular, the characterization of the nearby natural resources-and therefore, is considered as a component of the landscape of the project area. These resources should be promoted and connected throughout the city, thus revitalizing and integrating the urban landscape, rather than simply paving cobblestones without providing space for the flourishing of life, as has occurred in the past [29].

Such policy takes advantage of the existing infrastructure invested in the city, raising the quality of public spaces and the surplus value of urban sectors. The characteristics of the urban perspective incorporate with great relevance the zones of reforestation and conservation; these enabled researchers to determine that the passive techniques of recovery are the best alternatives for the increase of the biomass and the conservation of the environments influenced by mangroves or mountain ranges. The area of study is very close to the mangrove and mountain areas that were exploited as quarries in the past. The zoning merits a special emphasis to be placed on the management of soil, planting of native species, erosion control (trenches), and monitoring of plantations. The infrastructure for conservation stands out. Support infrastructure was implemented, such as a network of trails, recreational sectors, overnight accommodation, recreational activities, cycling trails, tourist trails, and educational and research areas, in this environment of mangrove ecological corridors.

From the relationship point of view, the Town Hall must perform the intervention for the recovery of public spaces, a policy that cannot be explicitly seen in municipal policies, nor in land use plans or in 
the partial plans, to such an extent that the public spaces in the city of Guayaquil are meagre; they do not reach $3000 \mathrm{~m}^{2}$, and neither the sidewalks nor the parks are included here. In this regard, it should be noted that the Delta Project contributes 22,754.54 $\mathrm{m}^{2}$, seven times more than that contributed by the local municipality [30].

Finally, this methodology should be incorporated into territorial planning plans and into other planning instruments, especially the management and participation system. The city of Guayaquil requires an administrative mechanism that takes charge of the planning, organization, direction, and control of the area, and that includes political support, interinstitutional and intersectoral coordination, and the participation of owners and the community in the integral corridor projects [31].

Many of the urban interventions, such as Puerto Liza, Estero Mogollón, and Estero Salado, were not conceived for the continuity of the concept of the ecological corridor, which could well serve as forms of education and preservation of natural resources; on the contrary, they covered them with fillers.

The project took eleven months to be developed; $30 \%$ of the time was used for the initial phase: that of preparation and forums. The project was developed in a short time using this collaborative system; in this sense, the living lab methodology fulfilled its mission: to achieve academic and professional results with a large input of management.

The vision described in this paper was presented to the International Sustainable Campus Network in Stockholm and the discussions conducted there with experts from different universities and associated fields generated the determination of the University of Guayaquil to establish a model of development and gain accreditation as a living lab, setting an example for other cities in the world with similar aspirations. The full implementation of this project will enhance the experience of many different users who study, work, visit, or reside and work within the area of influence of this urban campus of the largest public university in Ecuador.

Author Contributions: Conceptualization and project administration, H.H.; Methodology and formal analysis, F.E., H.H. and S.P.; Software and visualization, S.P., with the support of students in the living lab; Validation, H.H., F.E., I.M. and G.S.; Investigation, F.E. and H.H.; Resources and funding acquisition, E.O. and H.H.; Writing—original draft preparation, H.H.; Writing—review \& editing, I.M. and H.H.; Supervision, H.H.

Funding: This research was funded by the Municipality of Guayaquil (2019 budget) and University of Guayaquil Competitive Research Funding.

Acknowledgments: Administrative support: Ab. Jaime Nebot Saadi, Phd. Gulnara Borja Cevallos, Ing. Wilfrido Matamoros, Ab. Andrés Roche, Dra. Nathalie Marzo, Lcdo. Klever Loor, Arq. Freddy Olmedo, M. Sc Rosy Mendoza. Technical support: Ing. Eduardo Santos Baquerizo, Ing. Stalin Márquez, Ing. Víctor Hugo Verdezoto, Ing. Ramos, Eco. Fabián Vilema, Ing. Victor Párraga, Arq. Brick Reyes, Arq. Aurora Guaranda, Arq. Juan Carlos Torres, Arq. Luis Sagubay, Arq. Santiago Dick, Ing. Malena Marín, Arq. Marcela Blacio, Arq. Pamela Bermeo, Biologist Ph.D. Maritza Cárdenas, Biologist James Pepín Pérez, Biologist Luis Caicho, Graham Stagg, M. Sc Antonieta Morales, Arq. Luis Zuloaga, Arq. Cesar Antonio Knezevich, Ph. D Iván Paredes, Arq. Martha Donoso. Living Lab students: Verónica Rivadeneira, Steven Santistevan, Susana Peña, María Conchita, Paul Tinoco, Vincent Nader, Darwin Alcívar, Gabrielle Espinoza, Victor Moscoso, Gabriel Córdova, José Valdiviezo, and about 40 students of different faculties. Press: Blanca Moncada (Expreso Journal), Antonio Ruiz. Teleamazonas channel, and university press. Community leaders: Ana Herrera, Marcelo Santillán, Manuel Mera, bishop Miguel Matilla.

Conflicts of Interest: The authors declare no conflict of interest. 


\section{Appendix A}

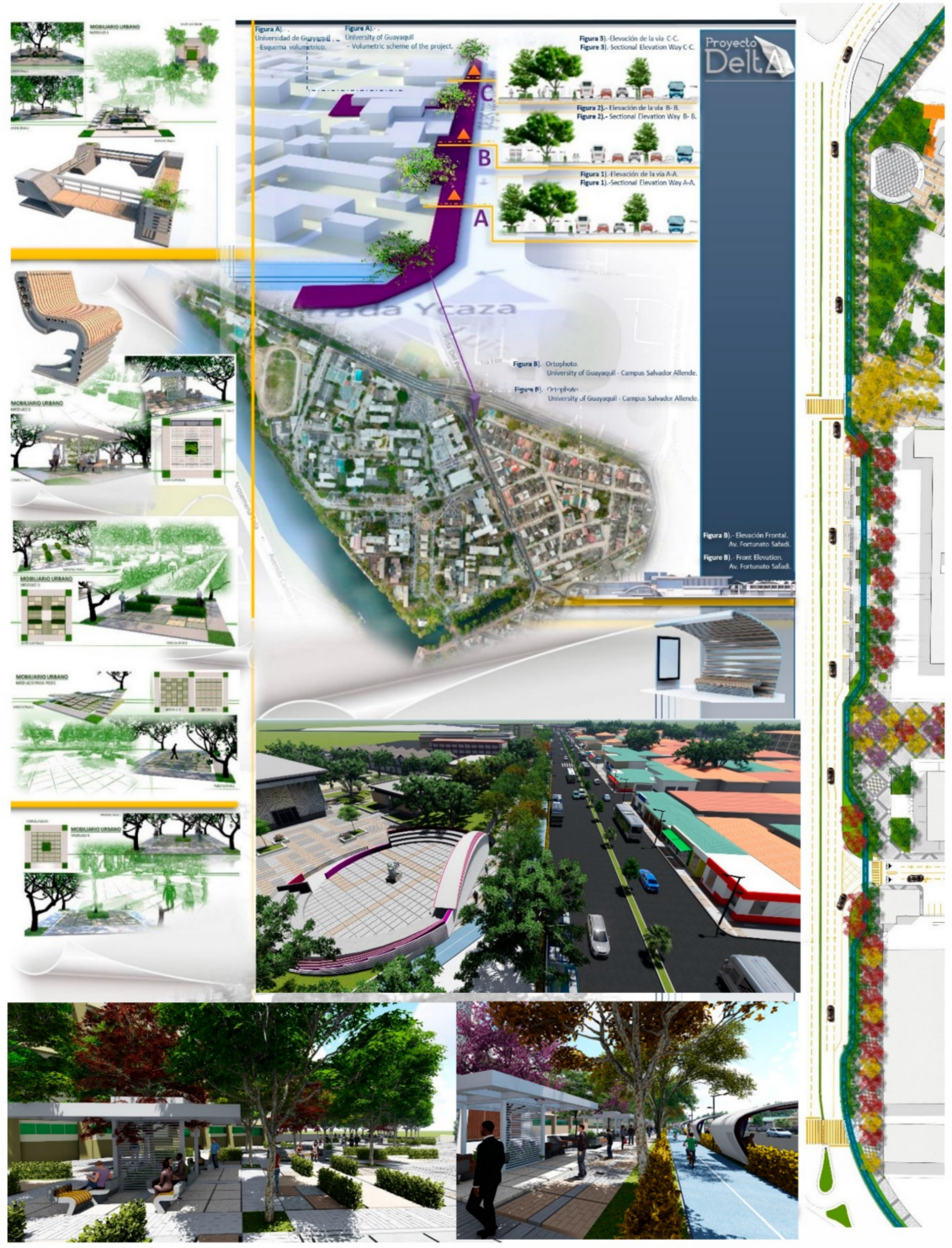

Figure A1. First stage of the Delta Project and its context area. Proposed situation: Copyright the authors.

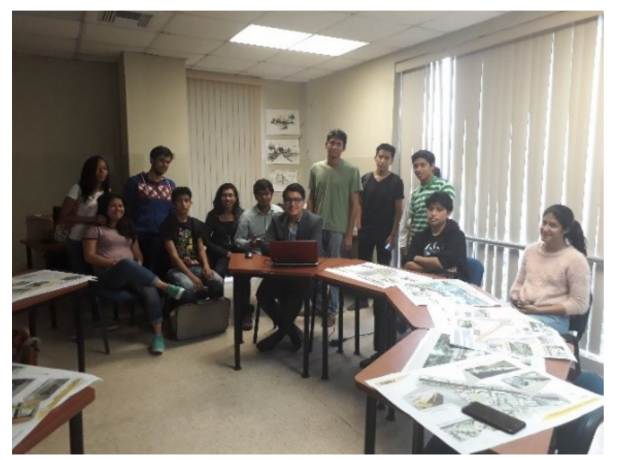

Figure A2. Working process. Own elaboration. Students participating in the project; faculty of architecture and urbanism, August 2017. 


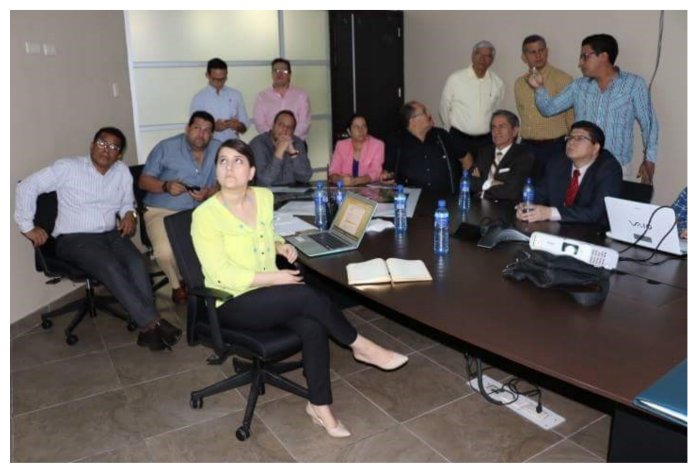

Figure A3. Working process. Own elaboration. Participation of authorities and technicians of the Municipal Transit Authority (ATM).

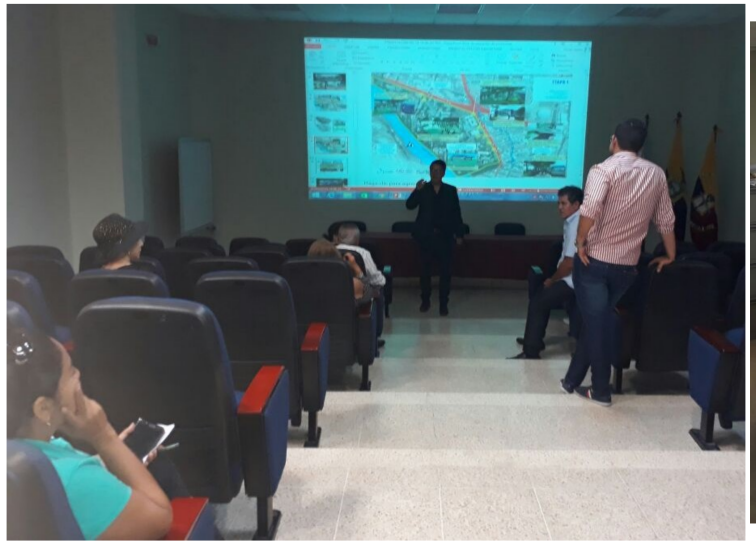

(a)

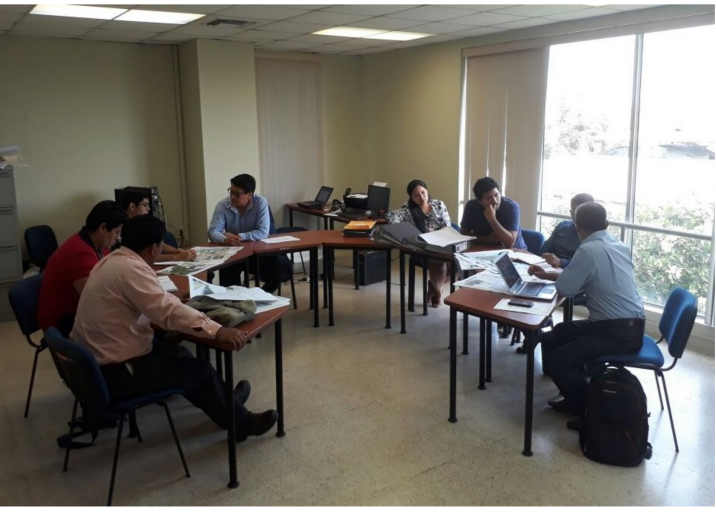

(b)

Figure A4. Working process. Own elaboration. (a) Participation of the leaders of residents of the Bolivarian district in the construction of public space. Faculty of architecture and urbanism, August 2017; (b) Participation of students and professors from various faculties, as well as external building experts for the Delta Project.

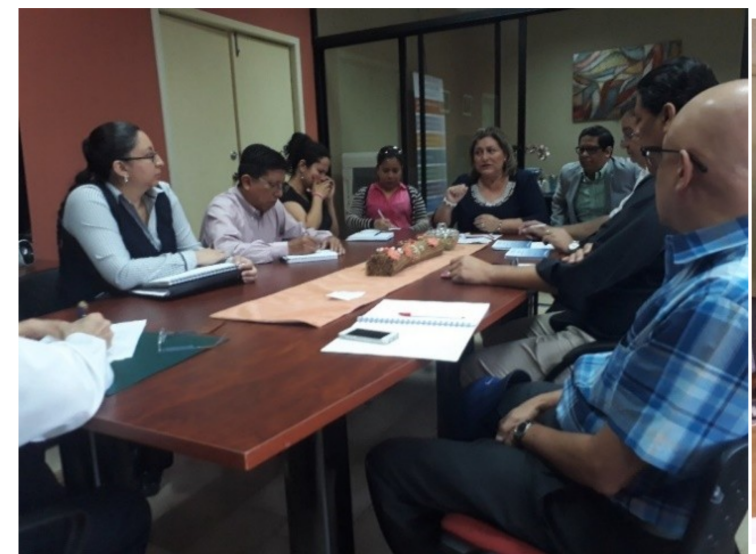

(a)

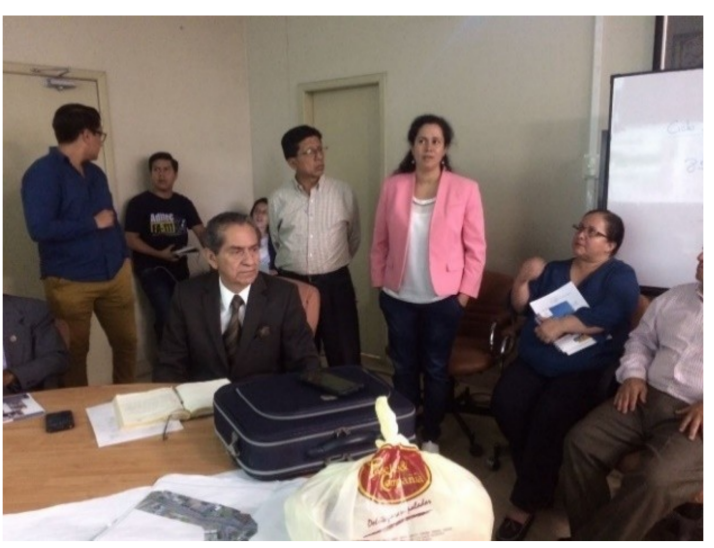

(b)

Figure A5. Working process. Own elaboration. (a) Construction and briefing of the Delta Project with the Vice-Rector for Research; (b) construction and briefing of the Delta Project with the members of the university council. 


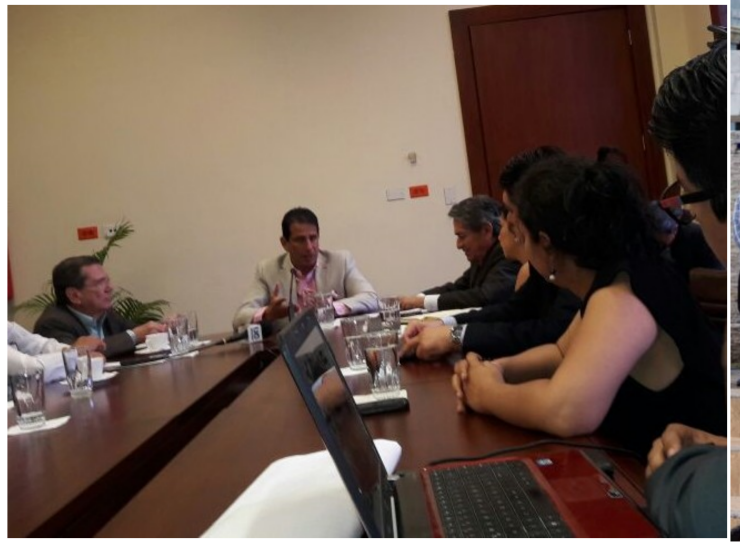

(a)

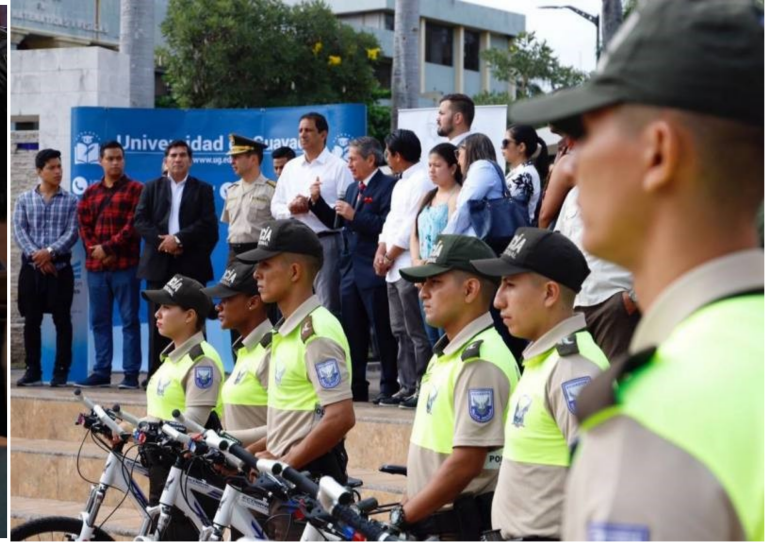

(b)

Figure A6. Working process. Own elaboration. (a) Delivery of urban and architectural studies of the Delta Project by the rector of the University of Guayaquil to the governor of Guayas, Francisco Cevallos. Governorate of Guayas, August 2017; (b) April, 2018: Inauguration of the Security Plan in the Salvador Allende Campus.

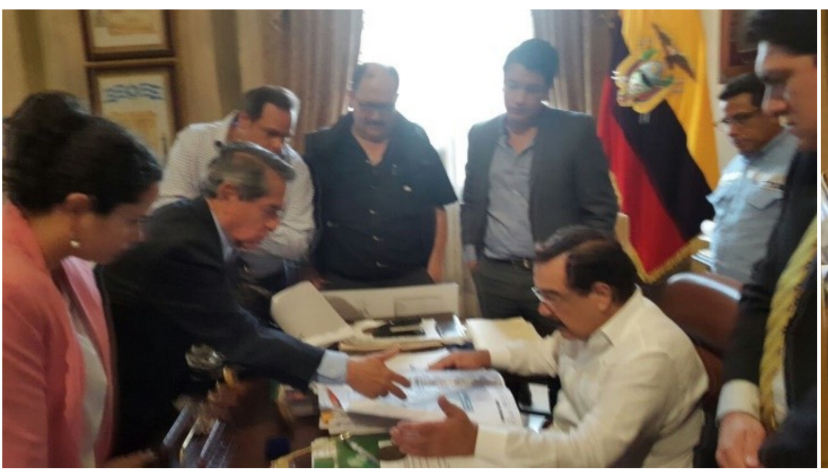

(a)

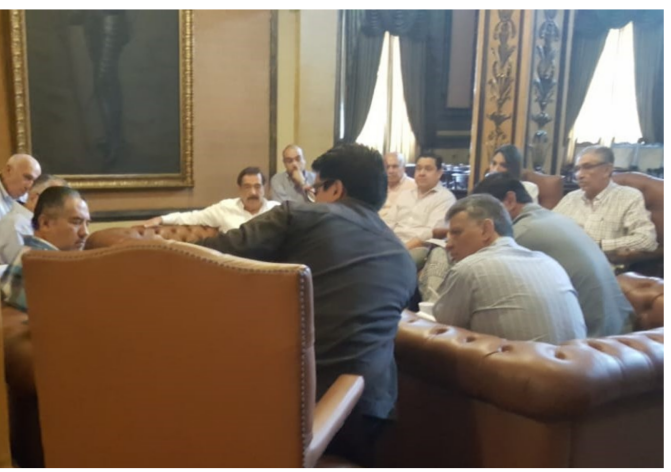

(b)

Figure A7. Working process. Own elaboration. (a) Delivery of the urban and architectural studies of the Delta Project by the rector of the University of Guayaquil to the city mayor, Jaime Nebot Saadi; Guayaquil Town Hall, August 2017; (b) Definition of commitments and sharing by the project director, the architect Héctor Hugo, to the mayor of the city of Guayaquil and the managers of the municipal foundations.

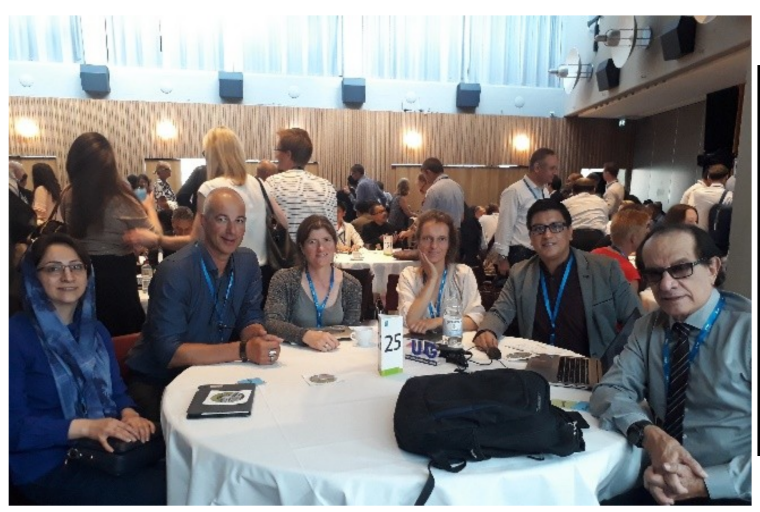

(a)

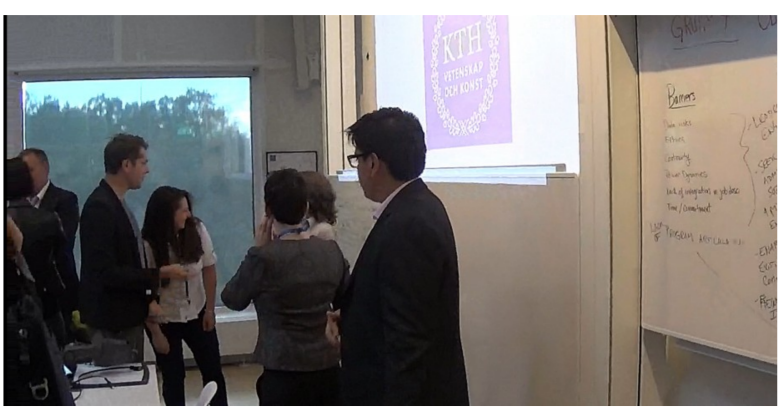

(b)

Figure A8. Working process. Own elaboration. (a) Guayaquil University, speaker at workstations; (b) participation of the Delta Project at a workshop about living labs, led by Julie Newman, Ph.D. of MIT. 


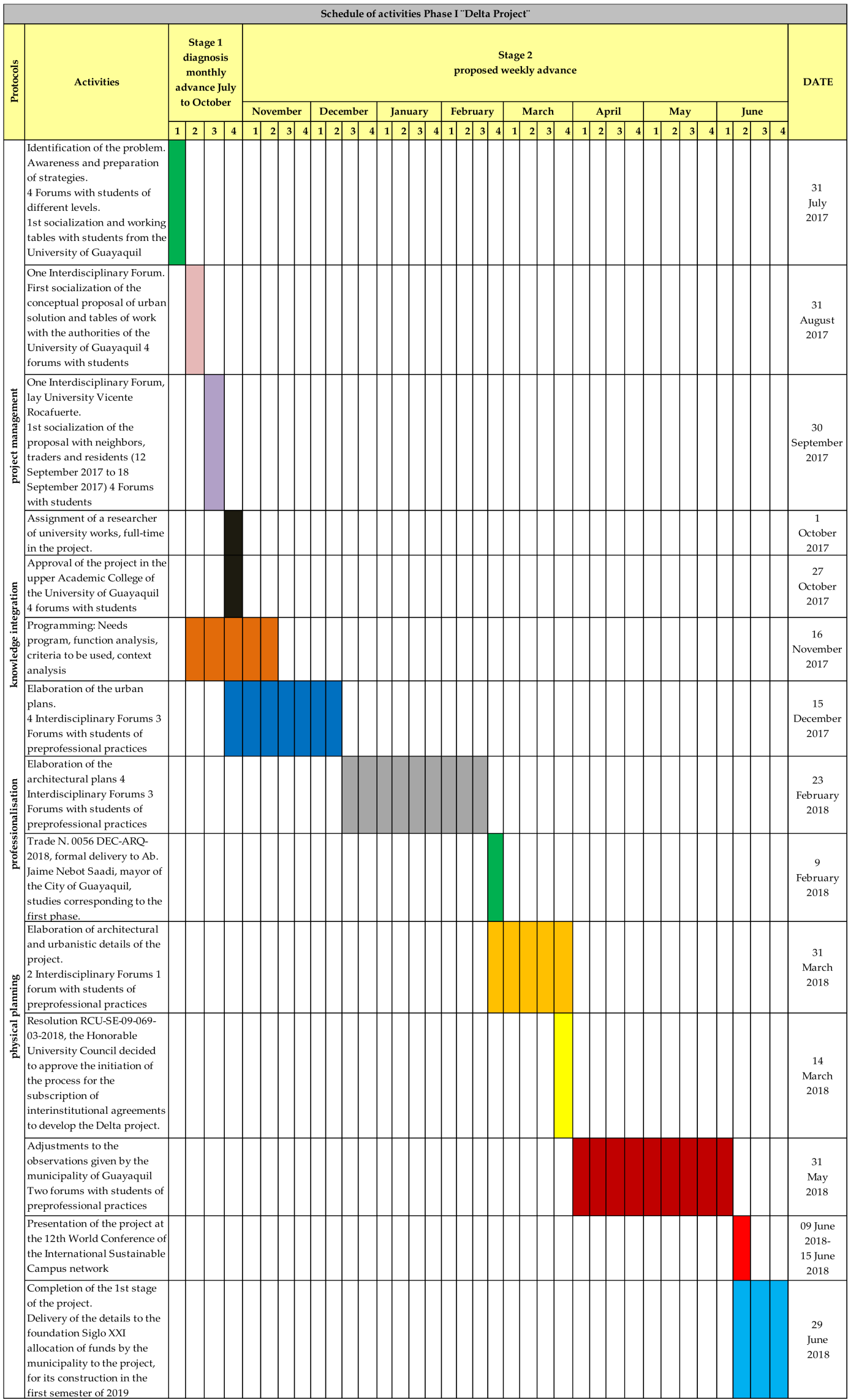

Figure A9. Schedule of activities developed in Phase 1 of the Delta Project. 


\section{References}

1. Romero-Lankao, P.; Gnatz, D.; Wilhelmi, O.; Hayden, M. Urban Sustainability and Resilience: From Theory to Practice. Sustainability 2016, 8, 1224. [CrossRef]

2. Los planos de Guayaquil: Dos Siglos de Evolución Urbana. Available online: http://biblioteca. culturaypatrimonio.gob.ec/cgi-bin/koha/opac-detail.pl?biblionumber=14153 (accessed on 9 August 2018).

3. Chini, C.; Canning, J.; Schreiber, K.; Peschel, J.; Stillwell, A. The Green Experiment: Cities, Green Stormwater Infrastructure, and Sustainability. Sustainability 2017, 9, 105. [CrossRef]

4. Zhao, P.; Chapman, R.; Randal, E.; Howden-Chapman, P. Understanding resilient urban futures: A systemic modelling approach. Sustainability 2013, 5, 3202-3223. [CrossRef]

5. Lozano, R.; Lukman, R.; Lozano, F.J.; Huisingh, D.; Lambrechts, W. Declarations for sustainability in higher education: Becoming better leaders, through addressing the university system. J. Clean. Prod. 2013, 48, 10-19. [CrossRef]

6. Cortese, A.D. The Critical Role of Higher Education in Creating a Sustainable Future. Plan. High. Educ. 2003, 31, 15-22.

7. Ferrer-Balas, D.; Adachi, J.; Banas, S.; Davidson, C.I.; Hoshikoshi, A.; Mishra, A.; Motodoa, Y.; Onga, M.; Ostwald, M. An international comparative analysis of sustainability transformation across seven universities. Int. J. Sustain. High. Educ. 2008, 9, 295-316. [CrossRef]

8. Jansen, L. The challenge of sustainable development. J. Clean. Prod. 2003, 11, 231-245. [CrossRef]

9. Lozano, R. Diffusion of sustainable development in universities' curricula: An empirical example from Cardiff University. J. Clean. Prod. 2010, 18, 637-644. [CrossRef]

10. Arquitectura i Sostenibilitat. Available online: www.mendeley.com/research-papers/arquitectura-isostenibilitat/ (accessed on 22 September 2018).

11. Altomonte, S. Environmental Education for Sustainable Architecture. Rev. Eur. Stud. 2004, 3, $12-21$. [CrossRef]

12. Koch, A.; Schwennsen, K.; Dutton, T.A.; Smith, D. The Redesign of Studio Culture: A Report of the AIAS Studio Culture Task Force. 2002. Available online: http:/ / scholar.google.com/scholar?hl=en\&btnG=Search\& q=intitle:The+Redesign+of+Studio+Culture:+A+Report+of+the+AIAS+Studio+Culture+Task+Force\#0 (accessed on 22 September 2018).

13. Verhoef, L.A.; Bossert, M.; Newman, J.; Ferraz, F.; Robinson, Z.P.; Agarwala, Y.; Wolff, P., III; Jiranek, P.; Hellinga, C. Towards a learning system for University Campuses as Living Labs for sustainability. In Universities as Living Labs for Sustainable Development: Supporting the Implementation of the Sustainable Development Goals; Springer: Stockholm, Sweden, 2018; Volume 2, pp. 1-14. (in press)

14. Masseck, T. Living Labs in Architecture as Innovation Arenas within Higher Education Institutions. Energy Procedia 2017, 115, 383-389. [CrossRef]

15. La Investigación Colaborativa. Procesos Colectivos de Creatividad. Available online: https://idus.us.es / xmlui/handle/ /11441/78489 (accessed on 22 September 2018).

16. Pont Vidal, J. Modelos Innovadores de Administración y Gestión Pública: Hacia la Emergencia de Nuevos Paradigmas. Gestión y Análisis de Políticas Públicas, 2016; pp. 6-26. Available online: http:/ / revistasonline. inap.es $/$ index.php?journal=GAPP\&page=article\&op=view\&path[]=10364 (accessed on 22 September 2018).

17. ¿Qué Democracia y qué Administración para la Nueva Época? Internet y la Gestión Pública. Available online: https: / / dialnet.unirioja.es/servlet/articulo?codigo=3966781 (accessed on 22 September 2018).

18. Rojas, A.; Valley, W.; Mansfield, B.; Orrego, E.; Chapman, G.E.; Harlap, Y. Toward Food System Sustainability through School Food System Change: Think\&amp;EatGreen@School and the Making of a Community-University Research Alliance. Sustainability 2011, 3, 763-788.

19. Gehl, J. Cities for People; Island Press: Washington, DC, USA, 2010; Volume 16, p. 269. Available online: http:/ / books.google.pt/books?id=1BNJoNILqQcC (accessed on 22 September 2018).

20. Bathrellos, G.D.; Skilodimou, H.D.; Chousianitis, K.; Youssef, A.M.; Pradhan, B. Suitability estimation for urban development using multi-hazard assessment map. Sci. Total Environ. 2017, 575, 119-134. [CrossRef] [PubMed]

21. Papadopoulou-Vrynioti, K.; Bathrellos, G.D.; Skilodimou, H.D.; Kaviris, G.; Makropoulos, K. Karst collapse susceptibility mapping considering peak ground acceleration in a rapidly growing urban area. Eng. Geol. 2013, 158, 77-88. [CrossRef] 
22. Armando, A.; Rosero, A. Espacio Público y Legislación. Discursos de Base en la Transformación de Ciudades en Colombia. 2013. Available online: http:/ / hdl.handle.net/2099/14173 (accessed on 22 September 2018).

23. Armando, A.R. La Transformación del Espacio Público; Entre Téoria Legislación y Practica: Estudio de Caso: La Ciudad de Villamaría; Universidad Católica de Manizales: Manizales, Colombia, 2007; Available online: http:/ / repositorio.ucm.edu.co:8080/jspui/handle/10839/367 (accessed on 22 June 2018).

24. El derecho al Espacio Público (The Right to Public Space). Available online: http:/ / search.ebscohost.com/ login.aspx?direct=true\&db=fua\&AN=97322675\&lang=es\&site=ehost-live (accessed on 22 September 2018).

25. Garrett, R.M. Issues in science education: problem solving, creativity and originality. Int. J. Sci. Educ. 1987, 9 , 125-137. [CrossRef]

26. Sosa, M.; Zarco, R.; Postiglioni, A. Modelando aspectos de grupo en entornos colaborativos para proyectos de investigación. Rev. Inf. Educ. Medios Audiov. 2006, 3, 22-31.

27. Sancén Contreras, F. La universidad del futuro. Red de Revistas Científicas de América Latina, el Caribe, España y Portugal, 2013; p. 17. Available online: http://www.redalyc.org/pdf/340/34030524002.pdf (accessed on 22 September 2018).

28. Del Medio Ambiente Al Espacio Público. Precisiones Conceptuales. From the Environment To Public Space. Available online: http:/ / www.redalyc.org/articulo.oa?id=29916108 (accessed on 22 September 2018).

29. Camargo, F.M. The Right to the City: From Henri Lefebvre to the Analysis about the Contemporary Capitalist City. Folios 2016, 2. Available online: http:/ /libezproxy.iyte.edu.tr:81/login?url=http:/ / search.ebscohost. com/login.aspx?direct=true\&db=edsdoj\&AN=edsdoj.49a31ac27cb242da97731f3703a1af3e\&site=eds-live (accessed on 22 September 2018).

30. Urban Configuration, Habitat and Appropiation of the Space. Available online: https://www.researchgate. net/publication/298486016_Urban_configuration_habitat_and_appropriation_of_the_space (accessed on 22 September 2018).

31. Driscoll Derickson, K. Seeking spatial justice. soja, edward w. Geogr. Ann. Ser. B Hum. Geogr. 2012, 94, 203-205. [CrossRef]

(C) 2018 by the authors. Licensee MDPI, Basel, Switzerland. This article is an open access article distributed under the terms and conditions of the Creative Commons Attribution (CC BY) license (http:/ / creativecommons.org/licenses/by/4.0/). 